\title{
Projected Changes in the Arctic Frontal Zone and Summer Arctic Cyclone Activity in the CESM Large Ensemble ${ }^{0}$
}

\author{
Alex D. Crawford and Mark C. Serreze \\ National Snow and Ice Data Center, Cooperative Institute for Research in Environmental Sciences, and \\ Department of Geography, University of Colorado Boulder, Boulder, Colorado
}

(Manuscript received 8 May 2017, in final form 28 August 2017)

\begin{abstract}
The Arctic frontal zone (AFZ) is a narrow band of strong horizontal temperature gradients that develops along the Arctic Ocean coastline each summer in response to differential heating of the atmosphere over adjacent land and ocean surfaces. Past research has linked baroclinicity within the AFZ to summer Arctic cyclone development, especially by intensifying storms that migrate northward from the Eurasian continent. This study uses the Community Earth System Model Large Ensemble in conjunction with an advanced cyclone detection and tracking algorithm to assess how the AFZ, summer Arctic cyclone activity, and the relationship between them respond to warming under the representative concentration pathway 8.5 (RCP8.5) scenario. Under this strong warming scenario, the AFZ remains a significant cyclone intensifier. Changes to the AFZ are largely restricted to June, when earlier snowmelt leads to strengthening of land-ocean temperature contrasts. This strengthening is accompanied by enhanced cyclogenesis along the east Siberian coast, but no change is observed for overall cyclone frequency over the Arctic Ocean. However, simultaneous changes to subpolar storm tracks impact Arctic cyclone activity in all summer months, sometimes in opposition to the impact of the AFZ. In June, the storms migrating poleward to the Arctic Ocean become weaker under RCP8.5, leading to lower Arctic cyclone intensity. In July and August, the poleward shift of the North Pacific storm track enhances cyclone activity in the Beaufort and Chukchi Seas.
\end{abstract}

\section{Introduction}

As the Arctic (Fig. 1) loses its summer sea ice cover, it becomes increasingly accessible for marine shipping, extraction of oil and natural gas resources, tourism, and other activities, all of which are affected by weather conditions. However, the same warming responsible for increased accessibility may also impact the generation and evolution of weather systems in the Arctic. These impacts are likely to be seasonally dependent, following seasonal variation in the dominant source regions for Arctic cyclones.

In autumn and winter, declining sea ice (Serreze and Stroeve 2008; Stroeve et al. 2012) may itself be a key driver of cyclone change. As the period of open water

Supplemental information related to this paper is available at the Journals Online website: https://doi.org/10.1175/JCLID-17-0296.s1.

Corresponding author: Alex D. Crawford, acrawford@wooster. edu lengthens, there will be stronger autumn and winter energy fluxes into the lower atmosphere, reducing static stability (Bengtsson et al. 2011; Jaiser et al. 2012; Rinke et al. 2013; Vihma 2014). Changes in the location of the ice margin will also alter local horizontal temperature gradient magnitude (Jaiser et al. 2012; Rinke et al. 2013). Declining sea ice cover will have less impact in summer when air-sea temperature contrasts are small (Long and Perrie 2012; Porter et al. 2012).

Changes in the polar jet stream may also be involved. In winter, a majority of cyclones migrating into the Arctic Ocean originate within the Icelandic low (IL) region and elsewhere along the North Atlantic storm track (Serreze et al. 1993; Simmonds et al. 2008; Crawford and Serreze 2016). These storms tend to travel northeastward; accordingly, the highest frequency of winter cyclones at Arctic latitudes is in the Barents and Kara Seas. Relatively few storms find their way into the central Arctic Ocean (CAO) or the Beaufort, Chukchi, East Siberian, and Laptev (BCEL) Seas (ibid.). Simulations from many climate models project a twenty-first-century reduction in Northern Hemisphere cyclone frequency (e.g., Finnis 


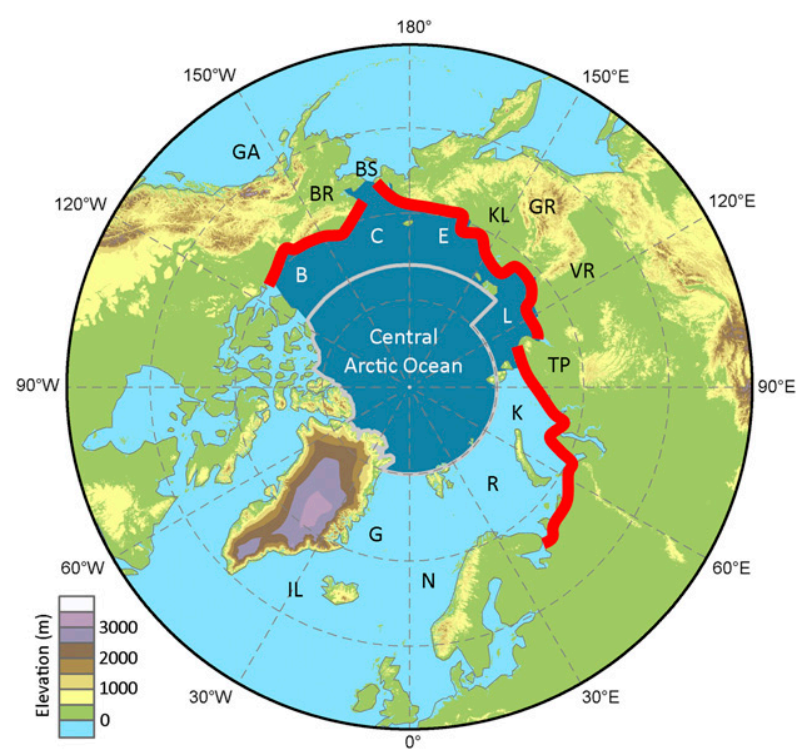

FIG. 1. Location map of Arctic region showing elevation (see color bar). The summer AFZ is outlined in red. The thick gray line bounds the $\mathrm{CAO}$, the surrounding letters denote the coastal Arctic seas [Beaufort (B), Chukchi (C), East Siberian (E), Laptev (L), Kara (K), Barents (R), Norwegian (N), and Greenland (G)], and the dark blue shading indicates the study area $(\mathrm{CAO}+\mathrm{BCEL})$. The letter pairs denote specific topographic features that are mentioned in the text (GA, BR, BS, KL, GR, VR, and TP).

et al. 2007; Pinto et al. 2007; Bengtsson et al. 2009; Ulbrich et al. 2009) but an increase or no change in frequency over the Arctic (e.g., Finnis et al. 2007; Ulbrich et al. 2013; Akperov et al. 2015). Such changes are often linked to a weakening and/or poleward shift in the polar jet stream, especially along the North Atlantic and North Pacific storm tracks (e.g., Pinto et al. 2007; Bengtsson et al. 2009; Ulbrich et al. 2009; Schuenemann and Cassano 2010; Chang et al. 2012; Lehmann et al. 2014).

Less attention has been paid to summer. Equator-topole temperature gradients, and therefore the polar jet stream, are weaker in summer, which means fewer cyclones in the North Atlantic Ocean and Barents Sea (Whittaker and Horn 1984; Serreze et al. 1993; Simmonds et al. 2008). Cyclones that do form along the North Atlantic storm track also tend to be less intense than their winter counterparts (Serreze et al. 1993; Serreze 1995; Simmonds and Rudeva 2014). However, cyclogenesis over Eurasia is much greater in summer than winter, especially in the Kolyma Lowland (KL), which lies in the lee of the Verkhoyansk range (VR) and Gydan range (GR) of Siberia (Serreze et al. 2001; Sorteberg and Walsh 2008; Crawford and Serreze 2016). Therefore, the response of summer cyclone activity in the Arctic to a warming climate may depend more strongly on the response of these Eurasian cyclones.
Summer cyclones migrating from Eurasia to the Arctic Ocean must pass through the Arctic frontal zone (AFZ; Fig. 2). As shown by Crawford and Serreze (2015), the AFZ is expressed along much of the Arctic Ocean coastline, from the Kola Peninsula $\left(41^{\circ} \mathrm{E}\right)$ and the Barents Sea in the west, along the shores of Siberia and Alaska, and ending around Banks Island $\left(126^{\circ} \mathrm{W}\right)$. Landward of the coastline, the surface heats up quickly after snow loss in May and June and readily transfers energy to the atmosphere via radiative and turbulent fluxes. Meanwhile, coastal parts of Arctic Ocean seas (except the Barents Sea) maintain sea ice cover into July and August and store more energy in the subsurface column, leading to lower air temperatures over the ocean (Crawford and Serreze 2015). This heating contrast leads to frequent near-surface weather fronts (Reed and Kunkel 1960; Serreze et al. 2001) and strong horizontal temperature gradients that extend into the mid- and upper troposphere (Fig. 2; see also Serreze et al. 2011; Crawford and Serreze 2015). Although the coastline itself is not a preferred area of cyclogenesis, Crawford and Serreze (2016) documented two ways in which the AFZ impacts cyclone development. First, they linked cyclogenesis over Siberia to troughing in the jetlike feature that develops in association with the AFZ (Figs. 2e-h). Second, they observed that variations in the strength of temperature gradients along the AFZ are positively correlated with both the intensification rate of cyclones passing through the AFZ and the average intensity of cyclones in the CAO and BCEL Seas $(\mathrm{CAO}+\mathrm{BCEL})$.

Conclusions drawn from previous studies of projected changes in summer Arctic cyclone activity have been mixed. Using a regional climate model to project out to the year 2100, Akperov et al. (2015) found no significant increase in overall April-September cyclone frequency, but they did find an increase in the number of small and weak cyclones as well as an increase in cyclone intensity. Using the Bergen Climate Model, Orsolini and Sorteberg (2009) found a reduction in summer cyclone frequency for the Northern Hemisphere as a whole but an increase in frequency poleward of $70^{\circ} \mathrm{N}$. Using an ensemble of 16 models and the Special Report of Emission Scenarios (SRES) A1B scenario, Lang and Waugh (2011) found no significant changes by 2100 in the number of Arctic cyclone centers in summer. However, using a similar 17-model ensemble, Nishii et al. (2015) found increased cyclone activity in the CAO by 2100 under the representative concentration pathway 4.5 (RCP4.5) scenario. [As shown in Fig. 12.3 of Collins et al. (2013), the top-of-the-atmosphere radiative forcing increases more slowly in the RCP4.5 than in the A1B scenario.] In addition to using different models and scenarios, 

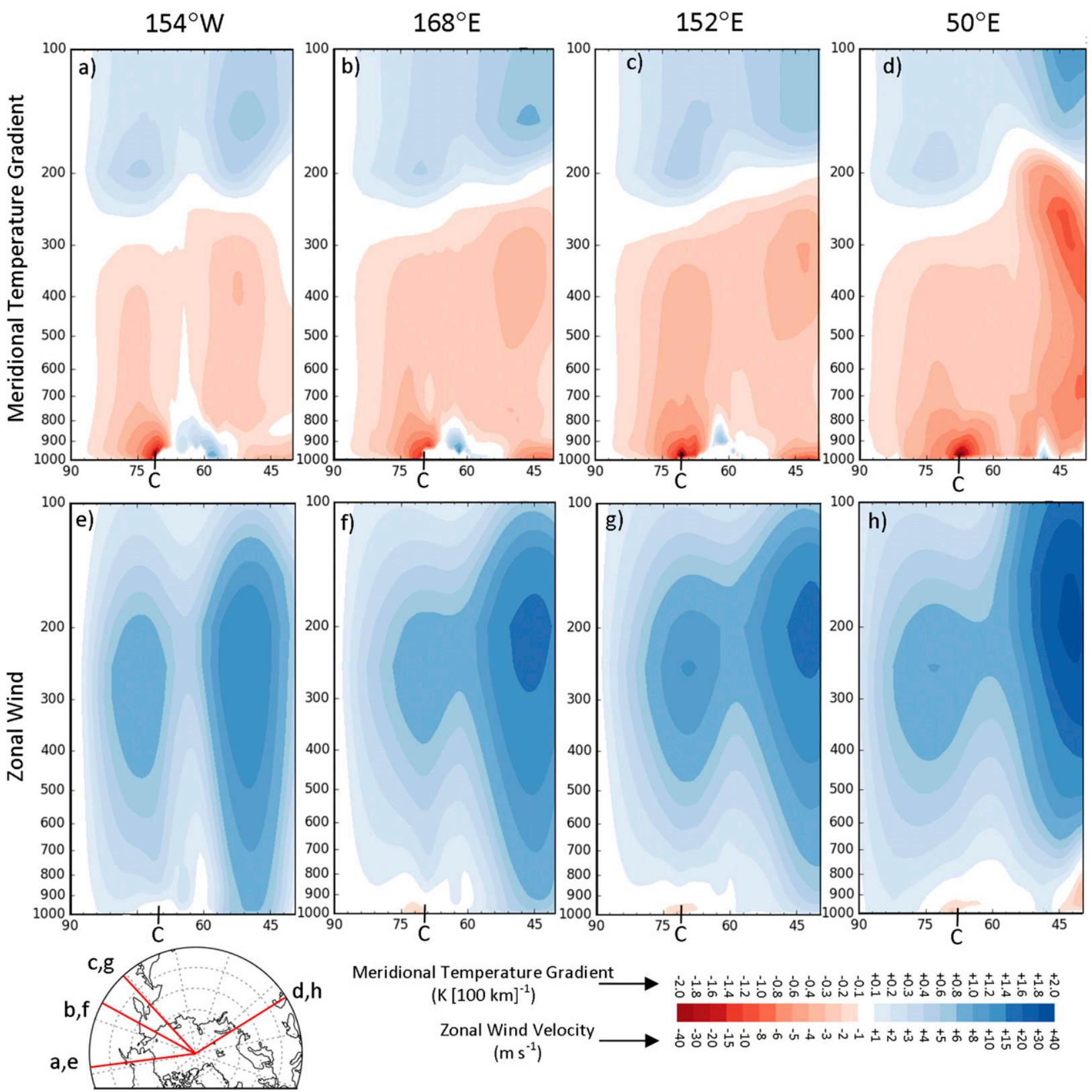

Meridional Temperature Gradient $\left(\mathrm{K}[100 \mathrm{~km}]^{-1}\right.$ )

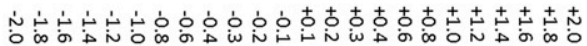

Zonal Wind Velocity $\left(\mathrm{m} \mathrm{s}^{-1}\right)$

FIG. 2. Latitudinal cross sections of the July 1990-2005 (a)-(d) meridional temperature gradient (cold to the north is negative) and (e)-(h) zonal wind velocity (westerlies are positive) in CESM-LE. Also marked is the Arctic Ocean coastline (C).

each of these studies uses different study areas, periods of analysis, and storm intensity/activity measures, all of which may influence results.

Although Orsolini and Sorteberg (2009) and Nishii et al. (2015) note an increase in coastal temperature gradients at the surface, neither of these studies closely examined the role of the AFZ. They also focused solely on seasonal changes, which may mask important changes at the monthly time scale. The purpose of this paper is to examine in detail how the AFZ impacts the response of summer Arctic cyclone activity to a strong warming scenario (RCP8.5) using the Community Earth System Model Large Ensemble (CESM-LE). The guiding questions are as follows:

1) How does the AFZ change in this strong warming scenario?

2) How does summer Arctic cyclone activity change in this strong warming scenario, and what role does the AFZ play? 


\section{Data and methods}

a. CESM-LE

The AFZ exhibits substantial interannual variability (Crawford and Serreze 2015) that might mask its response to the external forcings of RCP8.5 in a single model run. To account for this internal variability, changes in the AFZ and summer Arctic cyclone activity were assessed using members 1-30 of CESM-LE (Kay et al. 2015). Variations among ensemble members in CESM-LE arise from small round-off differences to the temperature field in the year 1920. These variations quickly propagate so that for the period 1990-2005, each member can be viewed as representing an independent expression of the same climate state. Differences represent the stochastic processes of internal variability, as described by Lorenz (1963) for the impact of initial conditions on numerical weather prediction models.

A complete description of the CESM-LE is provided by Kay et al. (2015). All simulations in the CESM-LE use version 1 of CESM (with Community Atmosphere Model, version 5; grid version $0.9 \times 1.25$ gx1v6; Hurrell et al. 2013), which includes coupled atmosphere, ocean, land, and sea ice components. It also incorporates a land carbon cycle and ocean biogeochemistry. Historical radiative forcing is used for the period 1920-2005, and RCP8.5 is used thereafter. RCP8.5 is a high-emissions scenario; in CESM, it has an anthropogenic radiative forcing of about $8.0 \mathrm{~W} \mathrm{~m}^{-2}$ at year 2100 (Collins et al. 2013).

CESM-LE data were obtained from Earth System Grid (https://www.earthsystemgrid.org/home.html) at about $1^{\circ}$ latitude-longitude spatial resolution. Monthly temperature, surface pressure, zonal wind, sea ice concentration, and snow fraction used here are available for the periods 1920-2005 (1850-2005 for member 1) and 2006-80. The vertical grid for CESM uses a hybrid pressure-sigma system, so wind and temperature data were first interpolated to a pure pressure grid with $50-\mathrm{hPa}$ intervals from 100 to $800 \mathrm{hPa}$ and $25-\mathrm{hPa}$ intervals from 800 to $1000 \mathrm{hPa}$.

Because the present study addresses cyclone evolution, subdaily temperature, sea level pressure (SLP), and precipitation data were also acquired. Temperature, SLP, and total precipitation are available from Earth System Grid at a 6-h temporal resolution for both 19902005 and 2071-80. [The former period has been extended by six years since Kay et al. (2015).] Large-scale precipitation is only available at a daily time scale.

One drawback to using CESM-LE instead of an ensemble of multiple climate models is the loss of information about model spread. To compensate for this loss, all results derived from CESM-LE through 2005 concerning the AFZ and summer Arctic cyclone activity were compared to the output from atmospheric reanalyses (see supplemental material sections 1 and 2, respectively). Relevant biases are also discussed in section 4 .

\section{b. Definition of AFZ strength}

As in Crawford and Serreze (2015), a $3 \times 3$ Sobel operator was used to calculate temperature gradient fields. A Sobel operator first calculates a zonal and meridional gradient and then combines them to find the magnitude, with the four cells sharing an edge with the center cell weighted twice as heavily as the four cells sharing a corner. Except for latitudinal cross sections, in which the meridional component along a single longitude is used, "AFZ strength" at any level of the atmosphere was defined as the average horizontal temperature gradient magnitude along the coastline of the Arctic Ocean from $42^{\circ} \mathrm{W}$ eastward to $126^{\circ} \mathrm{W}$.

\section{c. Summer NAM}

One test of robustness for the AFZ-Arctic cyclone relationship is whether it persists after controlling for large-scale atmospheric patterns that might also impact cyclone activity. One pattern that consistently shows a significant relationship with summer Arctic cyclone activity is the summer northern annular mode (NAM; Ogi et al. 2004; Serreze and Barrett 2008; Simmonds et al. 2008). For this study, a seasonally variable NAM (SVNAM; see Ogi et al. 2004) was computed separately for each calendar month. It is defined here as the leading empirical orthogonal function (EOF) of monthly SLP anomalies north of $40^{\circ} \mathrm{N}$.

\section{d. Cyclone detection and tracking}

Cyclone characteristics were calculated from the Lagrangian cyclone detection and tracking algorithm detailed by Crawford and Serreze (2016). SLP data are first reprojected using cubic convolution onto the Northern Hemisphere Equal-Area Special Sensor Microwave Imager (SSM/I) Grid 2.0 (EASE Grid 2.0; Brodzik et al. 2012) with a gridcell size of $100 \mathrm{~km} \times 100 \mathrm{~km}$. The EASE Grid 2.0 is based on a Lambert's equal-area azimuthal projection centered on $90^{\circ}$ latitude. To minimize issues with the extrapolation of SLP from elevation (Serreze 1995; Tilinina et al. 2013), all grid cells with an elevation $>1500 \mathrm{~m}$ are masked before the detection stage, and only cyclone tracks that spend at least one observation time at elevations under $500 \mathrm{~m}$ are used in analysis.

Cyclone centers are identified as minima in SLP. To remove heat lows and other spurious features, minima with an average radial pressure difference of less than $7.5 \mathrm{hPa}$ over a $1000-\mathrm{km}$ radius are rejected as cyclone centers. Cyclone area and multicenter cyclones are 
identified simultaneously based on the method described by Hanley and Caballero (2012). For multiple SLP minima to be part of the same multicenter cyclone they must all be within $1000 \mathrm{~km}$ of the lowest pressure minimum being considered. Additionally, if counting from that lowest minimum, the number of unshared isobars (surrounding just the lowest minimum) must be less than half the number of shared isobars (surrounding all minima without also surrounding an SLP maximum or an SLP minimum from another cyclone). The highest unshared isobar defines the area of a single-center cyclone, and the highest shared isobar defines the area of a multicenter cyclone.

Cyclone tracking relies on predicting the location of each cyclone center based on past propagation. Following Wernli and Schwierz (2006) and Hanley and Caballero (2012), the prediction vector is scaled by 0.75 to account for the tendency for cyclone propagation to decelerate with age. The nearest neighbor to this predicted location is identified as an extension of the cyclone track as long as the propagation speed does not exceed $150 \mathrm{~km} \mathrm{~h}^{-1}$.

\section{e. Cyclone characteristics}

Cyclone characteristics for this study were calculated on the subset of tracks that, in addition to passing the elevation criterion, had a track length of at least $100 \mathrm{~km}$ and a lifespan of at least $24 \mathrm{~h}$ (four time intervals). Additionally, although all cyclone centers were tracked individually, only one track is included here for each multicenter cyclone. Cyclogenesis and cyclolysis were recorded as the first and last appearance of a cyclone, respectively. In figures that follow, cyclogenesis and cyclolysis are mapped as the number of events per $500 \mathrm{~km} \times 500 \mathrm{~km}$ area per month or season. Similarly, cyclone frequency is mapped as "track density," or the number of tracks passing through a $500 \mathrm{~km} \times 500 \mathrm{~km}$ area per month or season.

As discussed by Simmonds and Keay (2000), all intensity measures have some drawbacks, so using multiple measures together provides a more comprehensive picture of cyclone activity. Cyclone intensity is measured using both the Laplacian of central pressure (DsqP) and cyclone depth, which is measured as the difference in pressure between a cyclone's center and its edge.

\section{f. $C A P$}

Cyclone-associated precipitation (CAP) links the AFZ to the hydrological cycle. The CAP calculation is based on Finnis et al. (2007) and Stroeve et al. (2011). First, for any given observation period, all areas of contiguous grid cells with a large-scale precipitation rate exceeding $1.5 \mathrm{~mm}$ day $^{-1}$ were identified. Second, all precipitation areas were assigned to a cyclone if 1) the precipitation area intersected the cyclone area or 2) the precipitation area lay within $250 \mathrm{~km}$ of the cyclone center. The cyclone area calculations are sensitive to cyclone "interference," leading to smaller cyclone areas when two separate systems lie close together. Using a minimum radius to determine intersections with precipitation areas alleviates this problem. However, the inclusion of cyclone area in addition to the minimum radius makes it more likely that larger cyclones will be associated with more precipitation. Third, the total precipitation for each precipitation area was assigned to its respective cyclone. Using total precipitation recognizes that convection can contribute precipitation within synopticscale systems. Finally, if one precipitation area was associated with multiple cyclones, the precipitation was partitioned among the cyclones so that each grid cell of precipitation was assigned to the nearest cyclone center.

Catto et al. (2012) apply a similar concept to identify precipitation associated with atmospheric fronts. If a front appears within a $2.5^{\circ} \times 2.5^{\circ}$ box centered on a grid cell with daily precipitation greater than zero, precipitation from that grid cell is associated with the front. Papritz et al. (2014) consider both cyclone- and frontassociated precipitation. Their CAP measurement is likely to identify less precipitation than the one used here since 1) they only assign precipitation to a cyclone if the precipitation grid cell falls within the cyclone area and 2) they do not use a minimum cyclone area for small storms. However, they also use a smaller contour interval $(0.5 \mathrm{hPa})$ for calculating cyclone area, which should make cyclone areas more accurate. All three methods result in cyclone-/front-associated precipitation climatologies with maxima along the major storm tracks.

\section{g. Climate change assessment}

To assess how the AFZ responds to warming under the RCP8.5 scenario, average monthly AFZ strength and zonal wind velocity were calculated for the periods $2071-$ 80 and 1990-2005 and compared using Student's $t$ tests ( $n=30$ for both periods). Cyclone intensity and frequency within the $\mathrm{CAO}+\mathrm{BCEL}$ and within the AFZ were assessed in the same manner. Assessing the response to warming as a difference between two periods rather than a continuous trend is also adopted by Orsolini and Sorteberg (2009), Akperov et al. (2015), and Nishii et al. (2015), whose results are compared in section 4.

The AFZ-cyclone relationship was examined by comparing the correlation between AFZ strength and cyclone characteristics during 1990-2005 and 2071-80. Because of the short periods being considered (16 and 10 years, respectively), a nonparametric Spearman's rho correlation coefficient was calculated for each member and period. 
TABLE 1. Mean June-August differences in temperature $\left({ }^{\circ} \mathrm{C}\right)$ between the years 2071-80 and 1990-2005 and $95 \%$ confidence interval based on 30 CESM-LE members. Differences are calculated at the near-surface (reference height) and 700-hPa levels both globally and for the Arctic (latitude $>60^{\circ} \mathrm{N}$ ).

\begin{tabular}{lcccr}
\hline \hline \multirow{2}{*}{ Period } & \multicolumn{2}{c}{ Near surface } & & \multicolumn{2}{c}{$700 \mathrm{hPa}$} \\
\cline { 2 - 3 } \cline { 5 - 5 } & Global & Arctic & Global & Arctic \\
\hline June & $3.24 \pm 0.02$ & $4.59 \pm 0.08$ & $3.61 \pm 0.02$ & $4.40 \pm 0.07$ \\
July & $3.27 \pm 0.02$ & $4.73 \pm 0.07$ & $3.69 \pm 0.03$ & $4.76 \pm 0.06$ \\
August & $3.30 \pm 0.02$ & $5.50 \pm 0.08$ & $3.66 \pm 0.03$ & $4.96 \pm 0.06$ \\
Summer (JJA) & $3.27 \pm 0.02$ & $4.94 \pm 0.07$ & $3.65 \pm 0.02$ & $4.71 \pm 0.05$ \\
\hline
\end{tabular}

Additionally, a correlation test was performed for all members combined, treating each member year as an independent observation. This averages out the internal variability that can be prominent over a 10 - or $16-\mathrm{yr}$ period. Finally, following Crawford and Serreze (2016), SVNAM-adjusted values were obtained for AFZ strength and each cyclone characteristic by calculating the residuals of a simple linear regression with the SVNAM index as the right-hand variable. The same correlation tests were also performed on these adjusted values to test whether the SVNAM might be considered the underlying cause of any AFZ-cyclone relationships found in CESM.

\section{Results}

RCP8.5 at 2071-80 represents a transient response to increased greenhouse gas concentration, which exerts a radiative forcing of about $7 \mathrm{~W} \mathrm{~m}^{-2}$ by 2075 (Collins et al. 2013). In CESM-LE, this results in an increase of $3.27^{\circ} \pm$ $0.02^{\circ} \mathrm{C}$ (Table 1 ) for the global near-surface air temperature during northern summer (JJA) between 1990-2005 and 2071-80. Continuing RCP8.5 past 2100 would result in a stabilized radiative forcing of about $12 \mathrm{~W} \mathrm{~m}^{-2}$ after 2200 (Collins et al. 2013).

Table 1 also shows the temperature change for the Arctic region (north of $60^{\circ} \mathrm{N}$ ). The mean summer nearsurface air temperature for the Arctic increases by $4.94^{\circ} \pm 0.07^{\circ} \mathrm{C}$. This is $1.67^{\circ} \mathrm{C}(51 \%)$ more than for the planet as a whole. In June, this Arctic amplification of warming near the surface is due primarily to enhanced warming over land (Fig. 3a). In July, differences between warming over ocean and continents are smaller, and continental enhancement is restricted to the Taymyr Peninsula (TP), the edge of Greenland, and the Canadian Arctic Archipelago (Fig. 3b). In August, the edge of Greenland shows the most warming, and parts of the Arctic Ocean warm more than Eurasia or North America (Fig. 3c). In other words, Arctic amplification transitions from being a primarily continental phenom enon in June to being a primarily oceanic phenomenon in August. Broadly consistent with observations
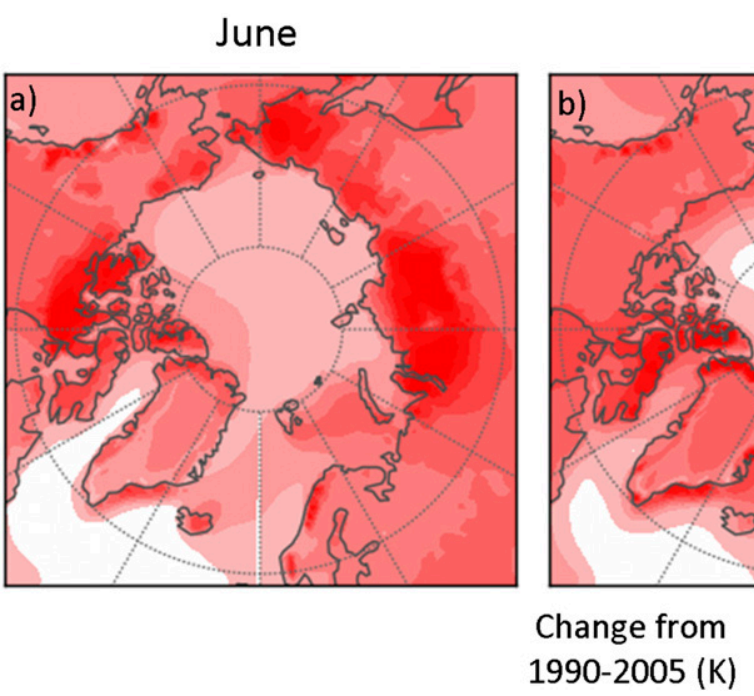

July

\section{(1)}
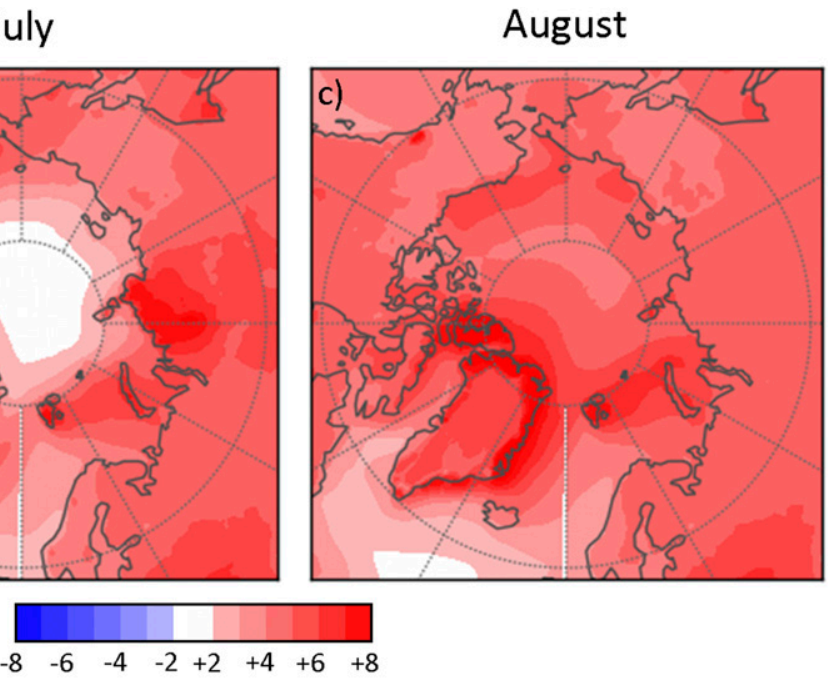

FIG. 3. Mean June-August differences in temperature between 2071-80 and 1990-2005 at reference height for CESM-LE members 1-30 under RCP8.5. All colored grid cells have a significant difference based on the $95 \%$ confidence interval of the Student's $t$ test in which each member is considered an independent observation (30 observations per period). 
(Serreze et al. 2009; Screen and Simmonds 2010; Pithan and Mauritsen 2014), Arctic amplification of warming is greatest near the surface, although still present aloft. At $700 \mathrm{hPa}$, the difference between Arctic warming and global warming is $1.06^{\circ} \mathrm{C}(35 \%)$. Warming is also more similar between low and high latitudes (Table 1) and nearly uniform between land and ocean (not shown).

\section{a. Response of the $A F Z$}

The near-surface response of the AFZ to Arctic warming is closely tied to the difference in warming over the continents and ocean. Warming in June is greater over the continents; accordingly, the temperature gradient magnitude strengthens along most of the Arctic Ocean coast (Figs. $4 a-c$ ), by more than $30 \%$ in some areas. In July, strengthening of coastal temperature gradients is largely restricted to the Taymyr Peninsula. In August, warming is greater over the ocean than over the continents, and parts of the AFZ weaken.

The seasonal cycle of the AFZ during the period 1990-2005 is strengthening in June, peak strength in July, and weakening in August. Therefore, the monthly changes that occur under RCP8.5 indicate a shift in AFZ seasonality. Under RCP8.5, the AFZ develops earlier. Indeed, in many years of the period 2071-80, coastal temperature gradients are strongest in June and begin declining in July.

Overall, changes to the AFZ are greatest at the lowermost levels of the atmosphere. However, as shown in Fig. 5, the changes in June extend through a varying depth of the atmosphere, depending on the region. These latitudinal cross sections from $40^{\circ}$ to $90^{\circ} \mathrm{N}$ depict the change in the meridional temperature gradient (Figs. 5a-d) and zonal wind velocity (Figs. 5e-h) between 1990-2005 and 2071-80. The cross sections for $154^{\circ} \mathrm{W}, 168^{\circ} \mathrm{E}, 152^{\circ} \mathrm{E}$, and $50^{\circ} \mathrm{E}$ cross the Arctic Ocean coasts of Alaska, Chukotka, eastern Siberia, and western Russia, respectively. In Figs. 5a-d, red indicates strengthening of cold-to-the-north temperature gradients. In Figs. $5 \mathrm{e}-\mathrm{h}$, red indicates strengthening of easterly winds (or weakening of westerly winds).

All cross sections show weakening of the polar front and jet at $40^{\circ}-45^{\circ} \mathrm{N}$, but with no poleward shift. The strong changes apparent from 250 to $200 \mathrm{hPa}$ result from expansion of the troposphere and lifting of the tropopause. The transects along $154^{\circ} \mathrm{W}$ and $168^{\circ} \mathrm{E}$ show strengthening of the AFZ that extends throughout the troposphere, as well as strengthening of its associated jetlike feature. The transect at $152^{\circ} \mathrm{E}$ captures similar patterns, but strengthening of the AFZ is restricted to lower levels of the atmosphere, and the westerlies exhibit no significant change. The cross section at $50^{\circ} \mathrm{E}$ is much different, depicting distinct weakening of the AFZ. Strengthening of the near-surface temperature gradients does occur offshore, but it is restricted to below $800 \mathrm{hPa}$.

Consistent with Fig. 4f, three of the four transects depict almost no change to the AFZ in July (Fig. 6). By contrast, changes to the polar front and tropopause are more prominent, and the polar front exhibits a clear poleward shift. Rather than along the coastline, the area of greatest surface change in the Arctic is over the Arctic Ocean. The one cross section showing substantial change over the coastline is along $154^{\circ} \mathrm{W}$ (Figs. 6a,e), where, despite the lack of strengthening near the surface (Fig. 4f), meridional temperature gradients and zonal winds both show widespread strengthening aloft.

The patterns described for July persist or intensify in August (Fig. 7). Winds become more westerly over much of the Arctic Ocean (except north of $85^{\circ} \mathrm{N}$ on the Pacific side). Despite little to no change at the surface, the AFZ strengthens over the Alaskan coastline above about $700 \mathrm{hPa}$. As discussed in section 4 below, the changes over Alaska in July and especially August may be driven by subpolar influences and not the surface contrasts associated with the AFZ.

\section{b. Response of summer Arctic cyclone activity}

As with the AFZ, the response of summer Arctic cyclone activity to $\mathrm{RCP} 8.5$ varies by month. Track density in June decreases throughout most of the midlatitudes, including along the North Atlantic and North Pacific storm tracks (Fig. 8c). Track density also decreases in the Barents, Kara, and Laptev Seas. Representing a shift in the North Atlantic storm track, the track density increases along the eastern side of Greenland. However, the area with the greatest increase in track density is the AFZ, extending from the Taymyr Peninsula, along the coastline of eastern Siberia and Chukotka, and across to the Arctic coastline of Alaska.

In July and August, widespread decreases in track density throughout the midlatitudes and a poleward shift of the North Atlantic storm track are still prominent. The Arctic sees some increases in track density, but these are focused over the Canadian Arctic Archipelago and Chukchi and Beaufort Seas rather than along the AFZ. The increased track density over the Taymyr Peninsula persists from June to July (Fig. 8f) but is absent in August (Fig. 8i).

Focusing more closely on the Arctic Ocean, Fig. 9 shows the change in cyclogenesis areas for the subset of cyclones that intersect the $\mathrm{CAO}+\mathrm{BCEL}$ region at any point during their life cycle. For all summer months and 

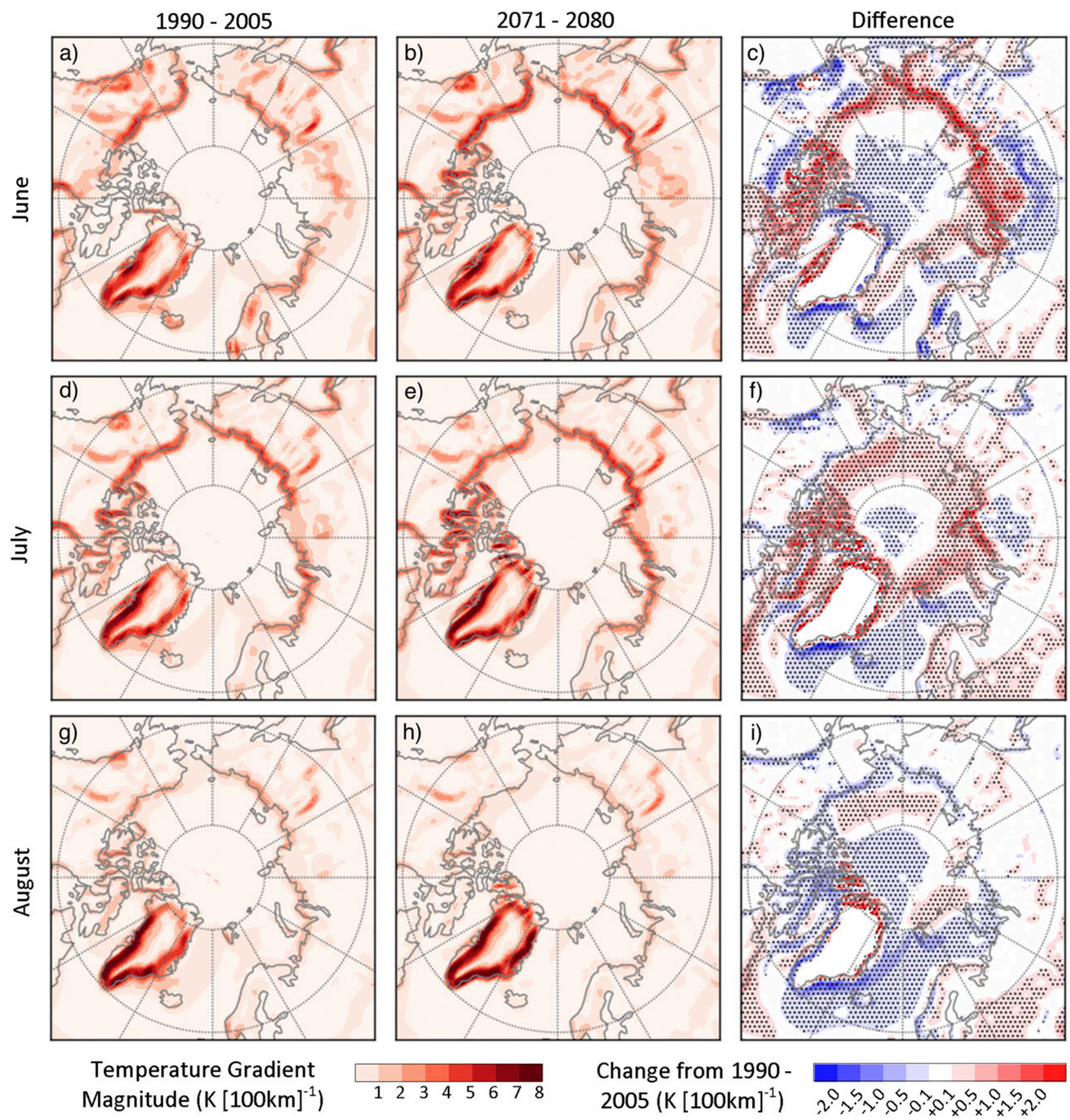

FIG. 4. Mean June-August 2-m horizontal temperature gradient magnitudes [K $(100 \mathrm{~km})^{-1}$ ] based on CESM-LE ensemble means for (a),(d),(g) 1990-2005 and (b),(e),(h) 2071-80 and (c),(f),(i) their difference. Stippling indicates a significant change based on the 95\% confidence interval of the Student's $t$ test in which each member is considered an independent observation ( 30 observations per period).

both periods, CESM-LE depicts the AFZ as a substantial source region for CAO+BCEL cyclones. (This represents a positive bias in CESM-LE; see Fig. S14 in the supplemental material.) In June, though, cyclogenesis in eastern Siberia becomes even more focused along the coastline under RCP8.5, and fewer cyclones originate farther inland. Despite some prominent changes in track density in the CAO+BCEL, neither July nor August exhibits the widespread changes to cyclogenesis seen in June. The largest areas of increased cyclogenesis in July and August are over the Taymyr Peninsula and northern Greenland, respectively. Hence, as with AFZ strength, widespread increases in AFZ cyclogenesis occur in June and June only. 

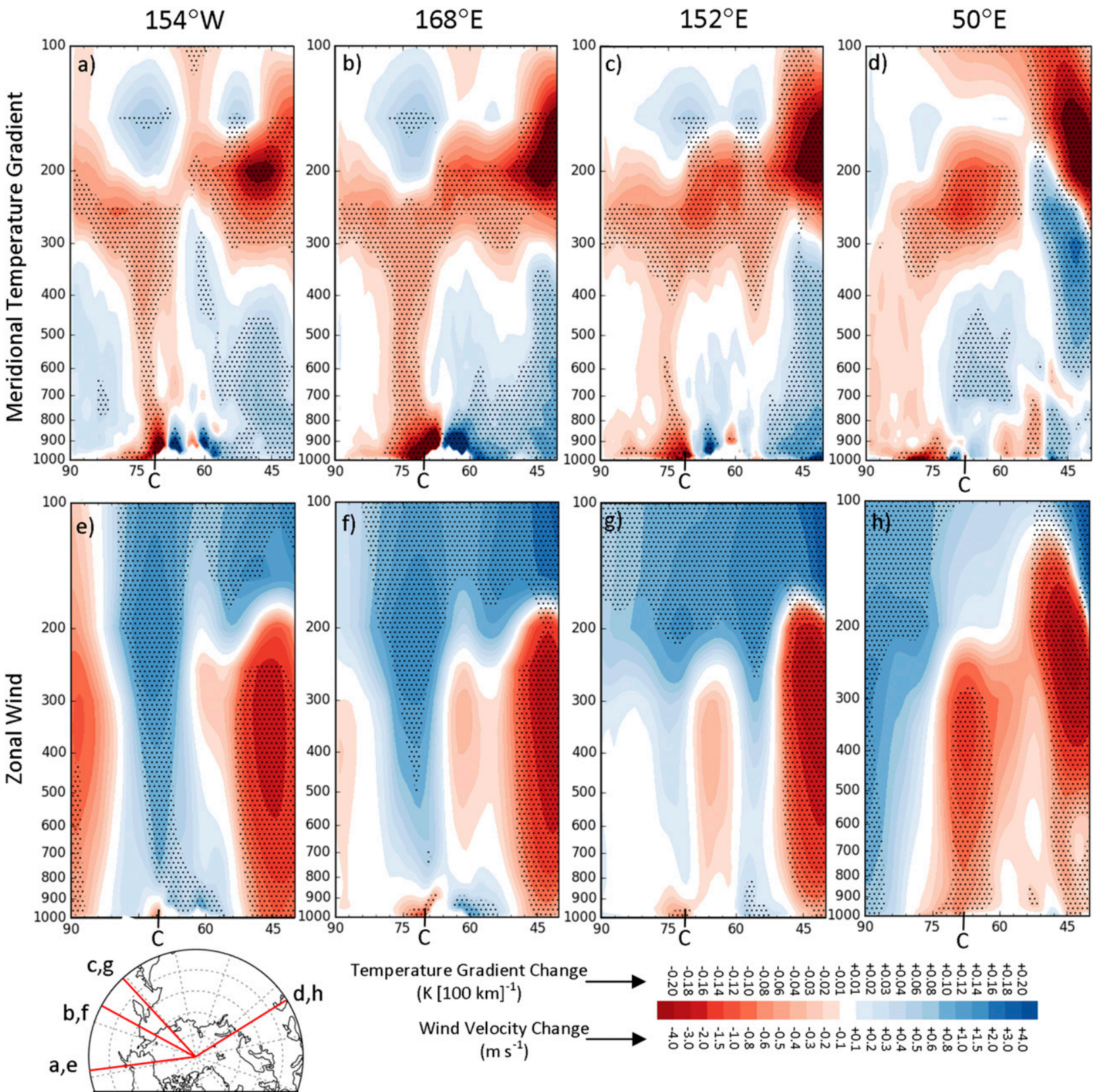

Temperature Gradient Change $\left(\mathrm{K}[100 \mathrm{~km}]^{-1}\right)$

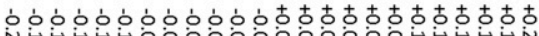

Wind Velocity Change $\left(\mathrm{m} \mathrm{s}^{-1}\right)$

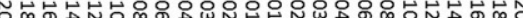

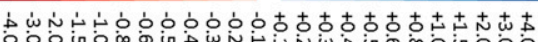

FIG. 5. Latitudinal cross sections of the difference in the June (a)-(d) meridional temperature gradient and (e)-(h) zonal wind velocity between 1990-2005 and 2071-80 under RCP8.5 in CESM-LE. Stippling indicates a significant change based on the 95\% confidence interval of the Student's $t$ test in which each member is considered an independent observation ( 30 observations per period).

Despite greater AFZ cyclogenesis in June, there is no significant change to track frequency in any summer month in the CAO+BCEL region (Table 2). The increased contribution of cyclones from the AFZ under $\mathrm{RCP} 8.5$ is offset by decreased contributions from elsewhere. For example, there is a decline from 1.02 to 0.85 cyclones per year $(p=0.03)$ from the combined area of the Kara, Barents, Greenland, and Norwegian Seas (at the northern end of the weakened North Atlantic storm track). Additionally, no significant change occurs in the number of cyclone tracks that intersect the AFZ. Recall from Fig. 9c that increased cyclogenesis along the AFZ is coupled with decreased cyclogenesis farther inland; the AFZ generates more cyclones, but this change is opposed by fewer storms forming farther inland.

Table 2 also lists the percentage change in average cyclone intensity and CAP within the CAO+BCEL. As with cyclone frequency, June is the only month with 

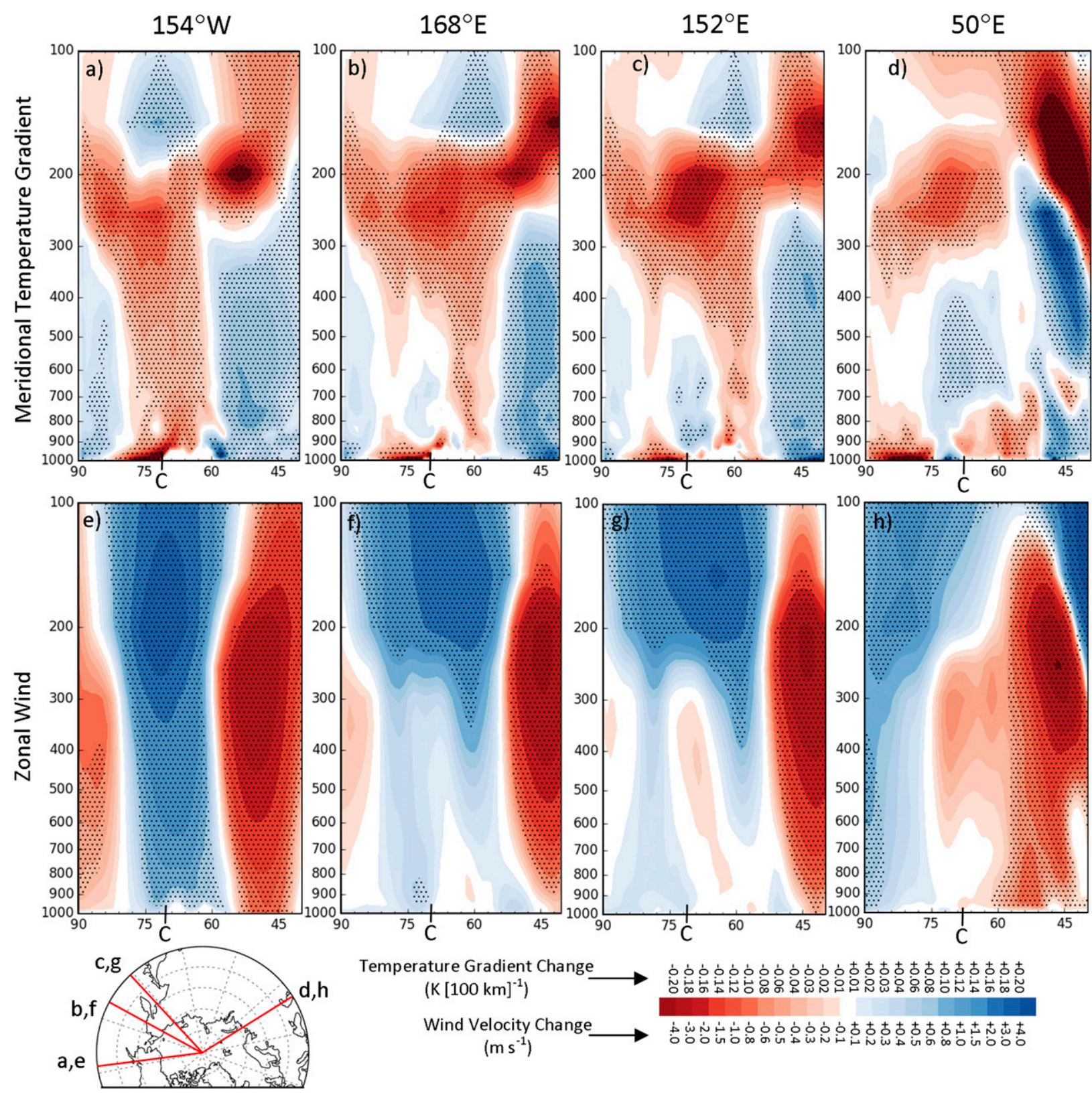

Temperature Gradient Change

$\left(\mathrm{K}[100 \mathrm{~km}]^{-1}\right)$

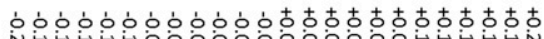

Wind Velocity Change

$\left(\mathrm{m} \mathrm{s}^{-1}\right)$

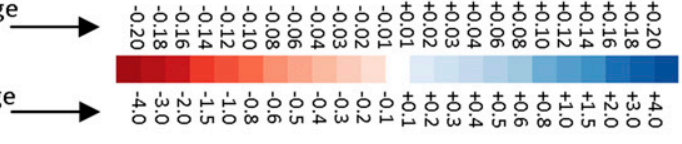

FIG. 6. As in Fig. 5, but for July.

significant changes to either cyclone depth or DsqP. Both measures indicate that cyclones are slightly but significantly weaker in 2071-80 than 1990-2005. By contrast, and likely pointing to the higher water vapor content of the warmer atmosphere, CAP increases substantially in all summer months, and most strongly in August.

Figure 10 shows the spatial patterns of monthly cyclone intensity change using DsqP. All months show cyclone weakening in the warmer climate throughout much of the midlatitudes. In all months, cyclones are weaker on the Atlantic side of the Arctic Ocean but stronger in some parts of the Pacific side. From June to August, the area of weakening becomes smaller while the area of strengthening becomes larger.

\section{c. Response of the AFZ-cyclone relationship}

The final consideration is the role of the AFZ as a cyclone intensifier in a warmer world. Following Crawford and Serreze (2016), Fig. 11 depicts the distribution of Spearman's correlation coefficients between AFZ strength and six cyclone characteristics for each 

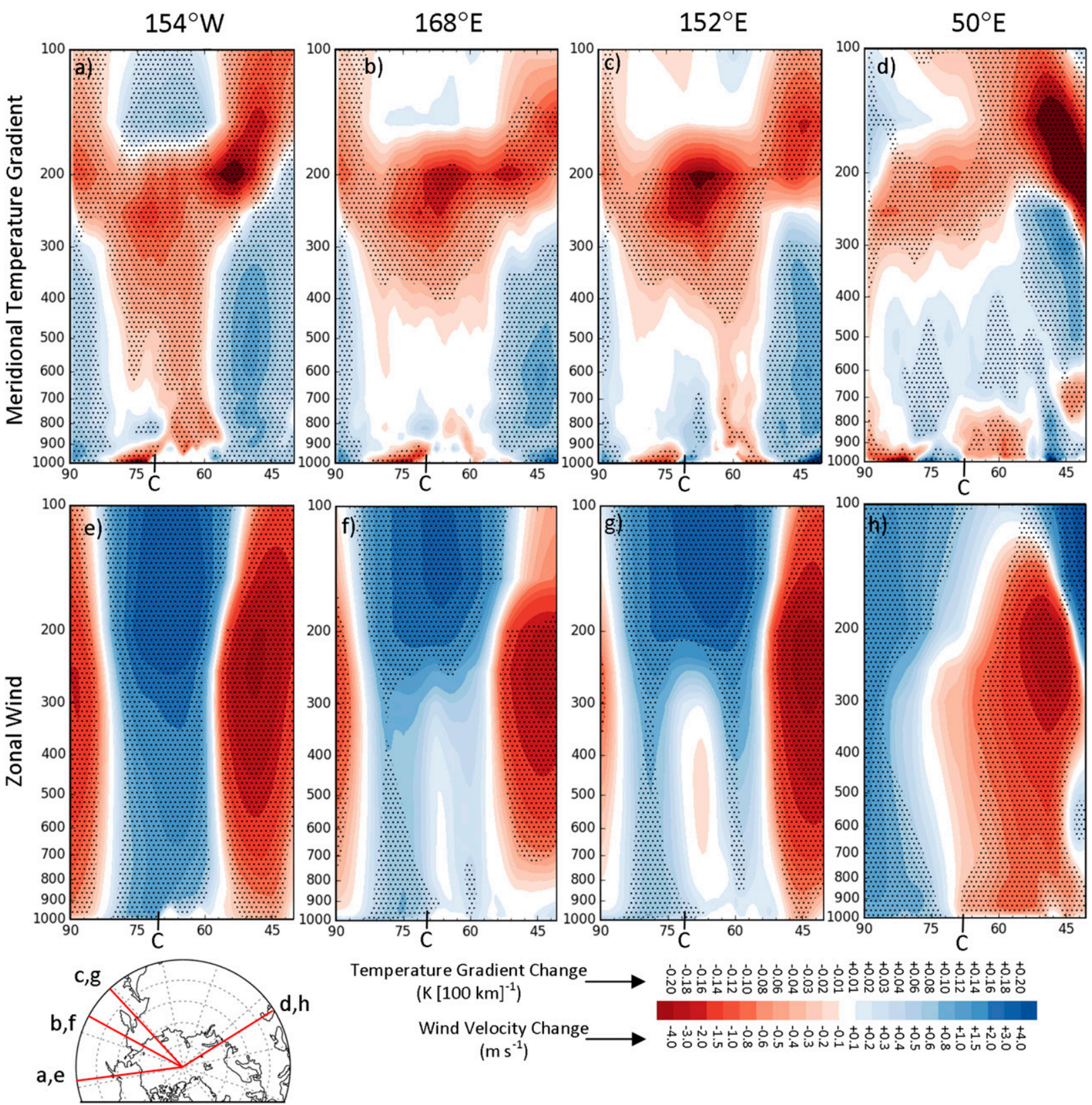

Temperature Gradient Change $\left(\mathrm{K}[100 \mathrm{~km}]^{-1}\right)$

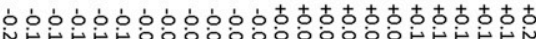
Wind Velocity Change $\left(\mathrm{m} \mathrm{s}^{-1}\right)$

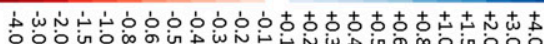

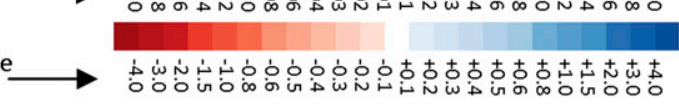

FIG. 7. As in Fig. 5, but for August.

CESM-LE member for 1990-2005 (black outlined bars) and 2071-80 (green bars). For most variables, the later period has a greater range of coefficient estimates. Rather than a more uncertain or erratic climate, this reflects the different number of observations in each period. Each member contains 16 years for 1990-2005 and 10 years for 2071-80. Recognizing this, correlation coefficients were also calculated combining all members, with 480 observations for 1990-2005 (black vertical line) and 300 observations for 2071-80 (green vertical line).
For all six variables, the climatological correlation coefficients (vertical lines) are very similar between periods. All three intensity measures have a modest correlation (0.30-0.50) with AFZ strength. A stronger AFZ means stronger summer cyclones. Additionally, at least 28 of the 30 members individually have a correlation with the same sign for each intensity measure despite the short records. The frequency measures all have positive but weak climatological correlations (below 0.30) and a wider spread in the coefficients from individual members. 

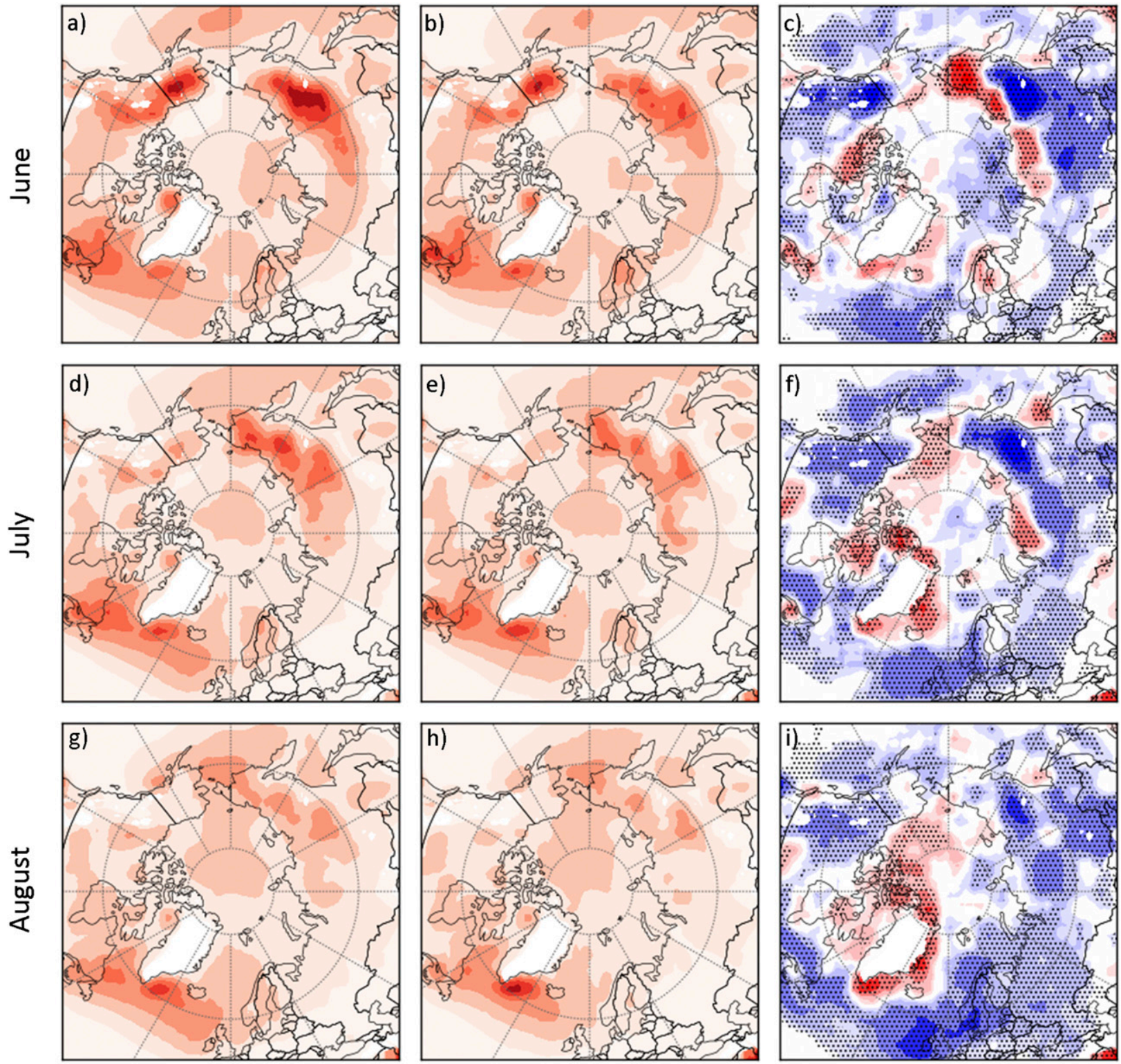

Units: tracks per 250,000 $\mathrm{km}^{2}$ per month

Track Density

$$
62^{2} 2^{8} \eta^{1} 3^{0} 3^{6} x^{2}
$$

\section{Change from 1990-2005}

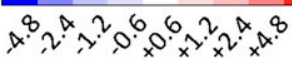

FIG. 8. Cyclone-track density for June-August averaged from CESM-LE for the periods (a),(d),(g) 1990-2005 and (b),(e),(h) 2071-80 and (c),(f),(i) their difference. Stippling indicates a significant change based on the $95 \%$ confidence interval of the Student's $t$ test in which each member is considered an independent observation (30 observations per period).

Controlling for the SVNAM does not substantially change the results. Figure 12 shows the same correlation results, only after removing the linear relationship of the SVNAM from both AFZ strength and the cyclone characteristics (see section $2 \mathrm{~g}$ ). Again, more variability among individual members is apparent in 2071-80 than in 1990-2005, but the climatological correlations are consistent. Removing the relationship with SVNAM weakens the correlations slightly, but a robust positive relationship is still apparent for both periods. Also consistent with Fig. 11, the frequency measures still show no clear relationship with AFZ strength after accounting for SVNAM. 

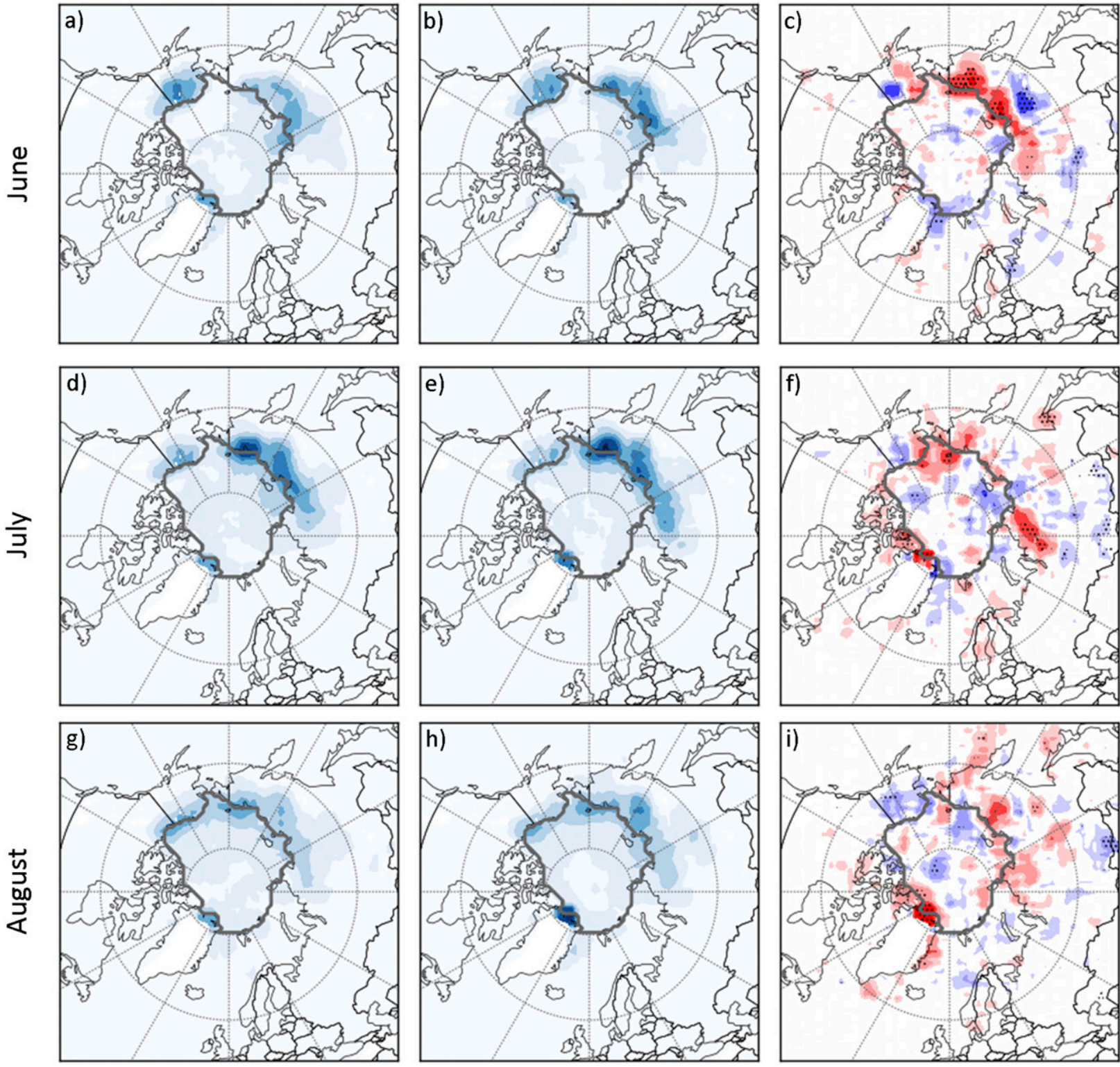

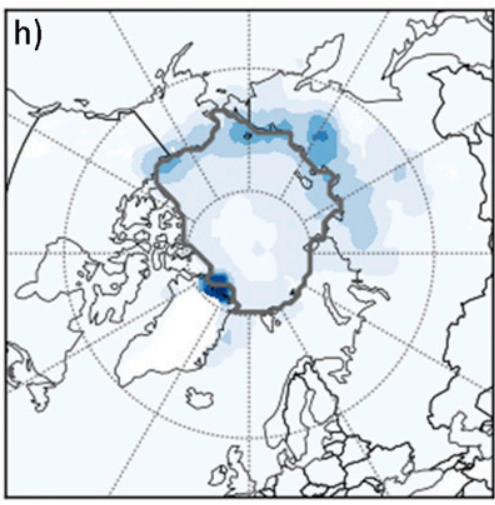

Genesis Frequency

$$
0.0 .0 .0 .0 .5
$$

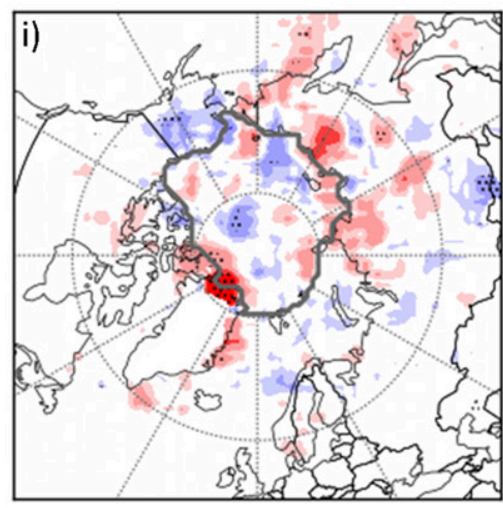

Change from 1990-2005

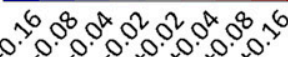

FIG. 9. As in Fig. 8, but for mean June-August cyclogenesis frequency for cyclones that spend any time over the CAO+BCEL region based on the CESM-LE ensemble mean.

\section{Discussion}

\section{a. Amplified Arctic warming and the AFZ}

As discussed earlier, the pattern of near-surface warming between 1990-2005 and 2071-80 varies both spatially and by month (Fig. 3). In June, warming over Arctic lands generally exceeds that over the Arctic Ocean, except along the Barents Sea coast. Contrasts between land and nearshore ocean areas diminish in July, and by August warming over the oceans dominates in some areas. The heterogeneity of temperature changes closely follows the seasonality of snow and sea ice loss (Fig. 13). Overall, the loss of June snow cover outpaces the simultaneous decline in nearshore sea ice concentration, leading to a greater albedo change for land than for the nearshore ocean. Additionally, the 
TABLE 2. Percent changes in cyclone variables from 1990-2005 to 2071-80 in CESM-LE (using RCP8.5). Boldface indicates significance at the $95 \%$ level, determined by the two-tailed Student's $t$ test. Intensity measures are averaged values for the CAO $+\mathrm{BCEL}$ region. Cyclone frequency is measured as the number of cyclones whose tracks intersect the area of interest. AFZ cyclogenesis is calculated as the average value for $500 \mathrm{~km} \times 500 \mathrm{~km}$ areas centered on each grid cell lying within the AFZ.

\begin{tabular}{|c|c|c|c|c|}
\hline Variable & June & July & August & Summer \\
\hline \multicolumn{5}{|c|}{ Intensity measures (averaged within the $\mathrm{CAO}+\mathrm{BCEL}$ ) } \\
\hline Cyclone depth & -7.7 & -3.5 & +0.2 & -3.6 \\
\hline DsqP & -3.4 & +0.4 & +0.6 & -0.8 \\
\hline CAP & +39.3 & +45.0 & +58.6 & +50.5 \\
\hline \multicolumn{5}{|c|}{ Frequency measures } \\
\hline AFZ cyclone frequency & +2.3 & +2.7 & -0.6 & +1.4 \\
\hline AFZ cyclogenesis & +18.3 & -0.1 & -3.6 & +4.7 \\
\hline $\mathrm{CAO}+\mathrm{BCEL}$ cyclone frequency & -0.4 & +1.4 & -0.2 & +0.3 \\
\hline
\end{tabular}

impact of the sea ice-albedo feedback has a characteristic time lag (Screen and Simmonds 2010; Serreze and Barry 2011). As the sea ice retreats in late spring and summer, more energy is absorbed within the ocean mixed layer (the top $20 \mathrm{~m}$ or so). When the sun sets in autumn and the atmosphere becomes cooler than the ocean surface, both turbulent fluxes are directed upward (ibid.). There is also a large upward longwave radiation flux from the open water surface. By contrast, the snowfree land will heat up quickly and hence also quickly heat the overlying atmosphere. Therefore, June snow loss amplifies warming immediately, while amplification from June sea ice loss exhibits a seasonal delay. One consequence, then, of RCP8.5 is that the AFZ develops more vigorously in June.

The AFZ strengthening in June is greatest at the surface and only occurs in areas experiencing substantial snow loss (Figs. 4 and 5). The lack of change in Eurasia for July and August can also be explained in terms of the seasonality of surface changes. Since even in 1990-2005 snow cover in CESM-LE is largely absent from coastal land by the end of June (consistent with observations; see Brown and Robinson 2011), less opportunity exists for amplified warming over Arctic land in July and August. Sea ice loss and enhanced ocean heat uptake are the dominant drivers instead. The one exception is along the Taymyr Peninsula. This is the only area with a substantial snow loss in July in the warmer climate and the only area where the AFZ strengthens in July.

Orsolini and Sorteberg (2009) and Nishii et al. (2015) both remark upon increased summer baroclinicity near the surface along the northern Eurasian coastline, but they looked at the summer season as a whole and used large spatial averaging. Our more detailed analysis reveals that strengthening of the AFZ occurs primarily in June. Additionally, although increases in the temperature gradient magnitude are widespread at the surface in this month, strengthening of the AFZ at higher atmospheric levels is restricted to coastlines bordering the
East Siberian, Chukchi, and Beaufort Seas, as is strengthening of the associated jetlike feature.

\section{b. Atlantic-side cyclone response in June}

Our results share some common ground with previous studies that have considered the summer cyclone response to climate warming. For instance, weakening and a northward shift of the North Atlantic storm track depicted in Fig. 8 is also seen in 1) the Bergen Climate Model under the SRES A1B and A2 scenarios (Orsolini and Sorteberg 2009), 2) the multimodel ensemble mean reported by Lang and Waugh (2011) under the A1B scenario, and 3) the CMIP5 ensemble under RCP4.5 (Zappa et al. 2013) and RCP8.5 (Lehmann et al. 2014). However, simulations under the A1B scenario with the HIRHAM model (Akperov et al. 2015) depict no such change. Both Orsolini and Sorteberg (2009) and Akperov et al. (2015) use a Lagrangian cyclone detection and tracking algorithm, and the choice of algorithm has been shown to have only a modest impact on projections of winter cyclone activity throughout the twenty-first century (Ulbrich et al. 2013). Therefore, the differences more likely stem from the choice of climate model and study season. Notably, whereas Akperov et al. (2015) considered April-September as their study season, the other four studies cited above used June-August.

Despite general similarities in the North Atlantic, CESM-LE yields some differences from past studies for June on the Atlantic side of the Arctic Ocean. In June, CESM-LE shows an overall decrease in cyclone intensity, mostly because of reductions along the Atlantic side of the Arctic Ocean (Fig. 10c). By contrast, Orsolini and Sorteberg (2009) found more intense cyclones (based on relative vorticity) in the CAO for the summer season. Using an Eulerian cyclone detection method, Nishii et al. (2015) likewise identified enhanced cyclone activity in the CAO during summer in an ensemble of 17 climate models under RCP4.5. Also unlike other 

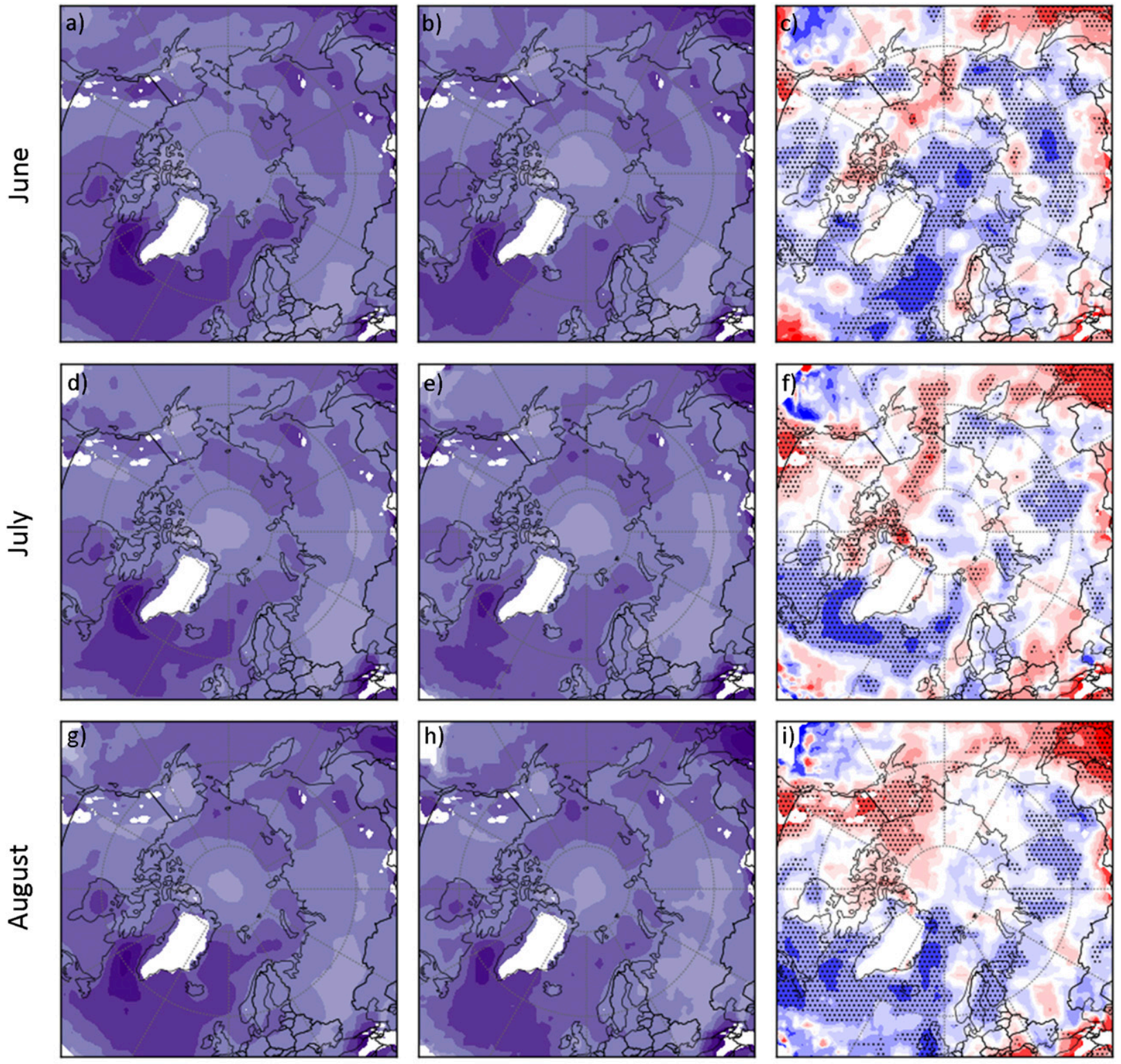

Units: hPa $(100 \mathrm{~km})^{-2}$

\section{DsqP}

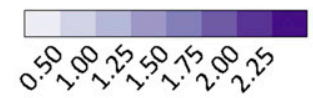

Change from 1990-2005

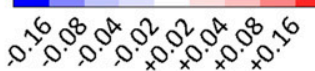

FIG. 10. As in Fig. 8, but for mean June-August DsqP (when a cyclone is present).

models, CESM-LE depicts declines in track density over the Barents and Kara Seas in addition to the North Atlantic Ocean. This may in part result from the difference in looking at monthly versus seasonal statistics. However, both Orsolini and Sorteberg (2009) and Nishii et al. (2015) depict increased cyclone activity in the CAO, and CESM-LE indicates no significant changes in July and August that might offset June declines for that area.
Additionally, both the weakening of $\mathrm{CAO}+\mathrm{BCEL}$ cyclones and the decline in track density in the Barents and Kara Seas shown in CESM-LE link in part to the North Atlantic storm track. Based on CESM-LE, cyclones migrating to the CAO+BCEL from the North Atlantic in June are both fewer in number and weaker under RCP8.5. For these storms, the difference in average $\mathrm{DsqP}$ is $-0.07 \mathrm{hPa}(100 \mathrm{~km})^{-2}(-4.4 \% ; p=0.02)$ before entering the $\mathrm{CAO}+\mathrm{BCEL}$ (see also Fig. 9c). 
a) Laplacian of Central Pressure

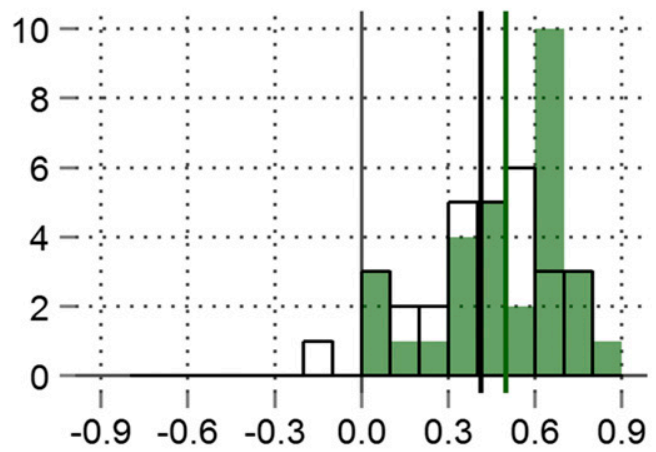

b) Cyclone Depth

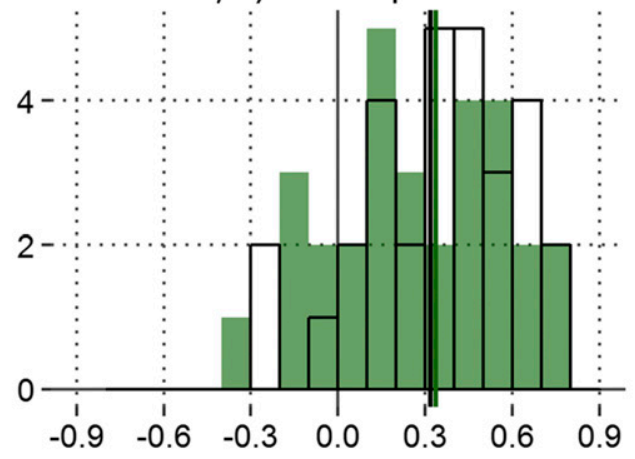

c) Cyclone-Associated Precipitation d) AFZ Track Frequency

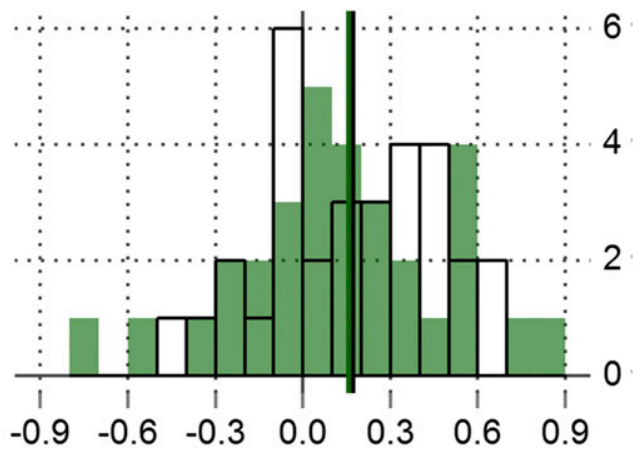

e) CAO+BCEL Track Frequency

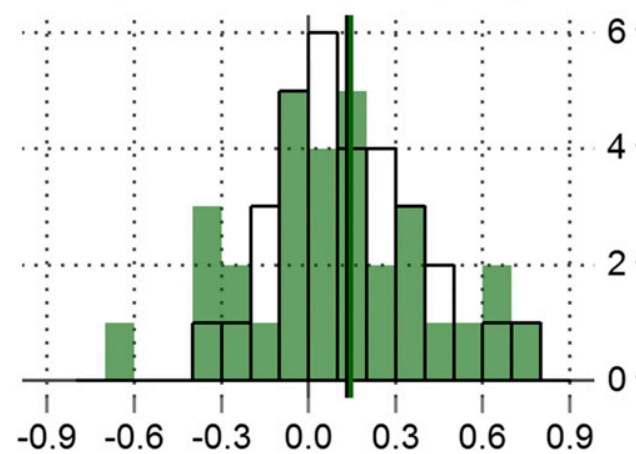

f) AFZ Cyclogenesis
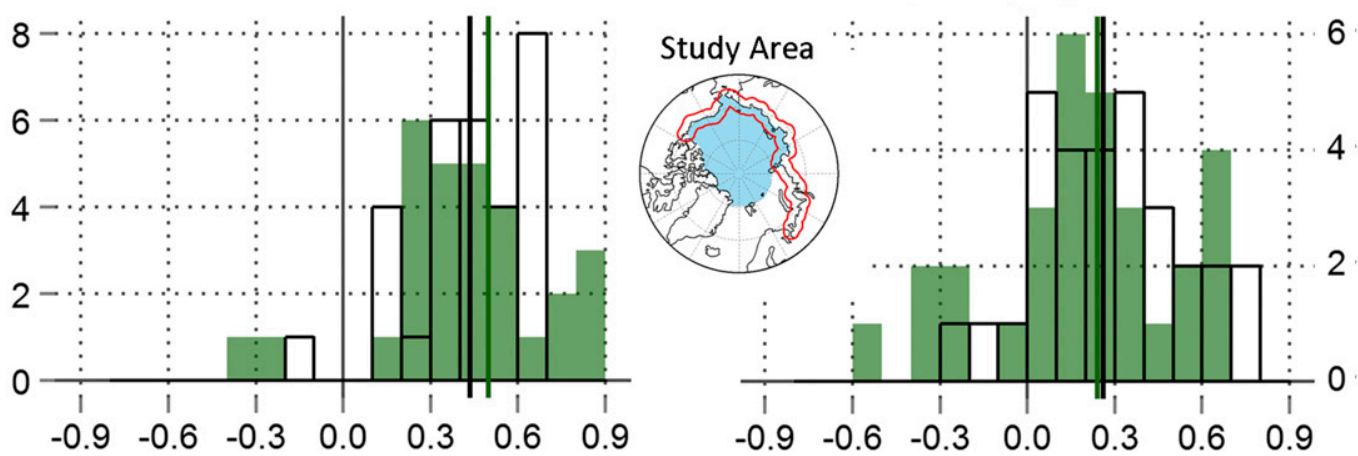

FIG. 11. Frequency plots of Spearman's correlation coefficients between AFZ strength at $700 \mathrm{hPa}$ and average (a) DsqP, (b) depth, and (c) CAP for cyclones in the CAO+BCEL region, as well as AFZ strength at $700 \mathrm{hPa}$ and the average number of tracks that (d) cross the AFZ (red outline in inset map), (e) cross the CAO+BCEL region (light blue in inset map), or (f) form in the AFZ for all summer months (JJA). Green solid bars show frequency for 2071-80, and black outlined bars show frequency for 1990-2005. The height of each bar indicates how many members for which the correlation coefficient falls within the bar's width. The green line marks the correlation coefficient that results when combining observations from all members for the 2071-80 correlation. The black line marks the same, only for 1990-2005.

Therefore, the discrepancy between CESM-LE and other model results may largely reflect differences in the behavior of the North Atlantic storm track in CESM compared to other models. In many climate models, the storm track is too zonal, with too many cyclones striking western and central Europe and too few tracking into the Greenland, Norwegian, and Barents Seas (Ulbrich et al. 2008). Although CESM underestimates cyclone frequency in the Kara Sea, it overestimates cyclone frequency in the Greenland and Norwegian Seas compared to atmospheric reanalyses (Fig. S11 in the supplemental material). Many studies agree that the North Atlantic storm track weakens under twenty-first-century warming scenarios, but this weakening seems to have a 
a) Laplacian of Central Pressure

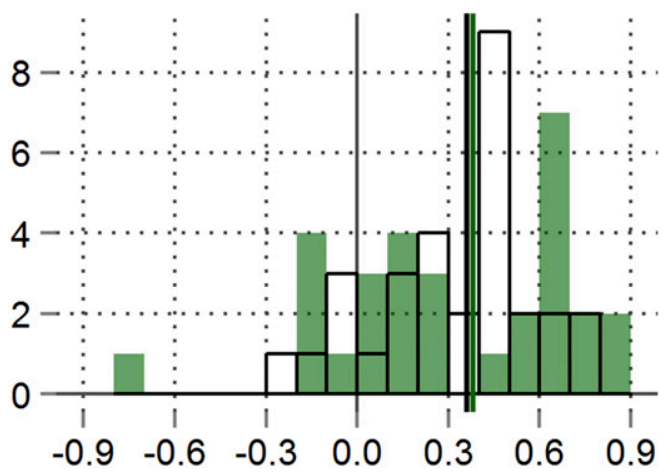

b) Cyclone Depth

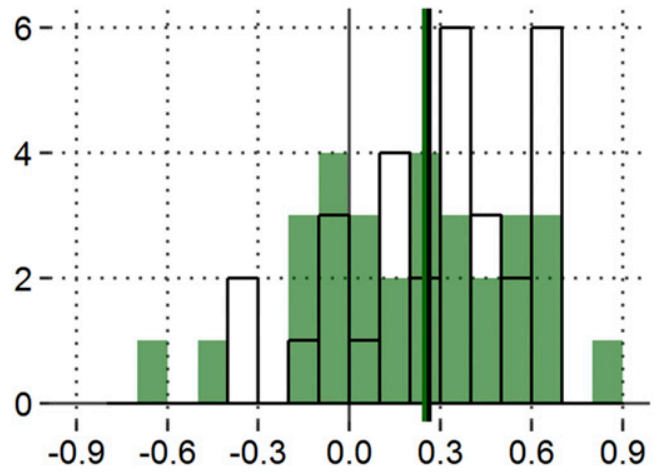

c) Cyclone-Associated Precipitation

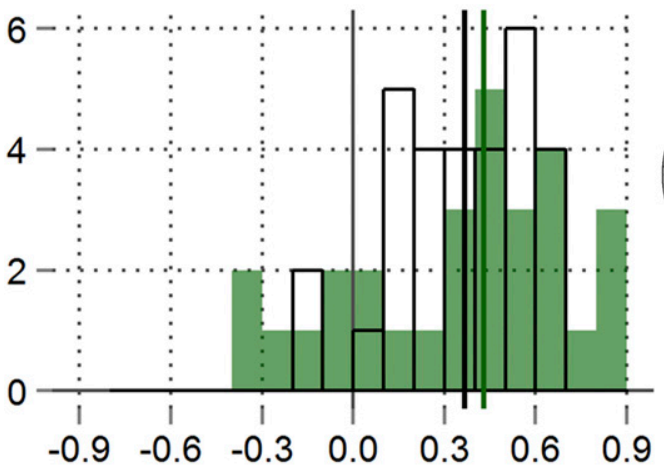

d) AFZ Track Frequency

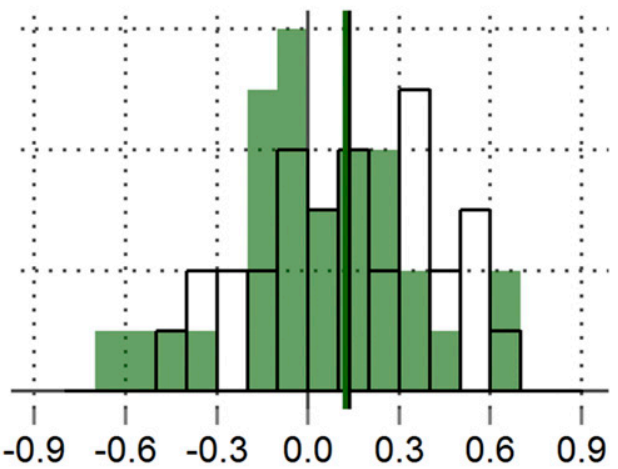

e) CAO+BCEL Track Frequency

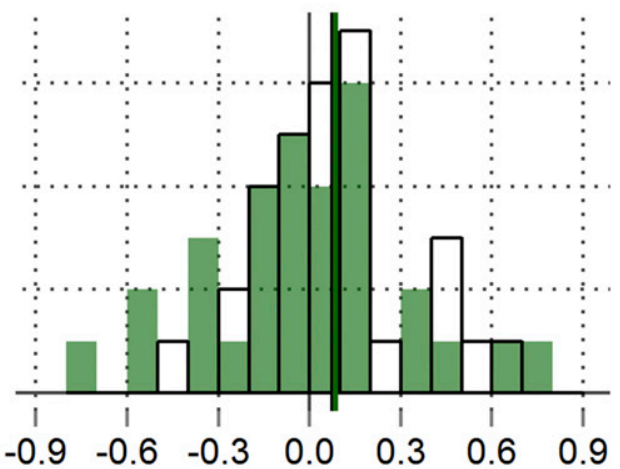

f) AFZ Cyclogenesis

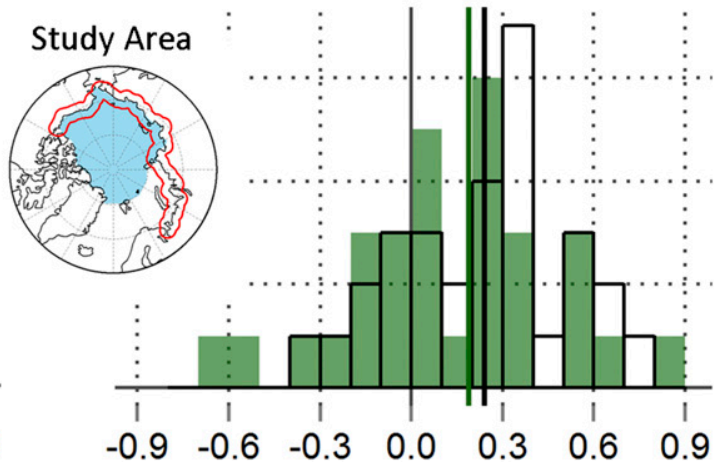

FIG. 12. As in Fig. 11, but with the effect of SVNAM first removed from all variables using a linear model.

greater impact on the summer Arctic in CESM because its North Atlantic storm track is less zonal and contributes a greater number of cyclones.

\section{c. Northern Eurasia cyclone response in June}

For storms migrating into the $\mathrm{CAO}+\mathrm{BCEL}$ from Eurasia, our results are most similar to those of Orsolini and Sorteberg (2009), especially in terms of cyclone frequency. In CESM-LE, increased track density over Eurasia is most persistent over the Taymyr Peninsula, occurring in both June and July. For other parts of the
AFZ, increased track density is restricted to June only, and these changes are diminished if looking at summer as a whole (not shown). This is consistent with Fig. 1 of Orsolini and Sorteberg (2009), which shows increased track density along the Siberian coast and, more specifically, depicts the Taymyr Peninsula as a relative maximum for increased cyclone frequency under future warming scenarios. Other studies show different results. Increases in cyclone activity detected by Nishii et al. (2015) are focused on the CAO. Akperov et al. (2015) identified small pockets of decreased frequency and 

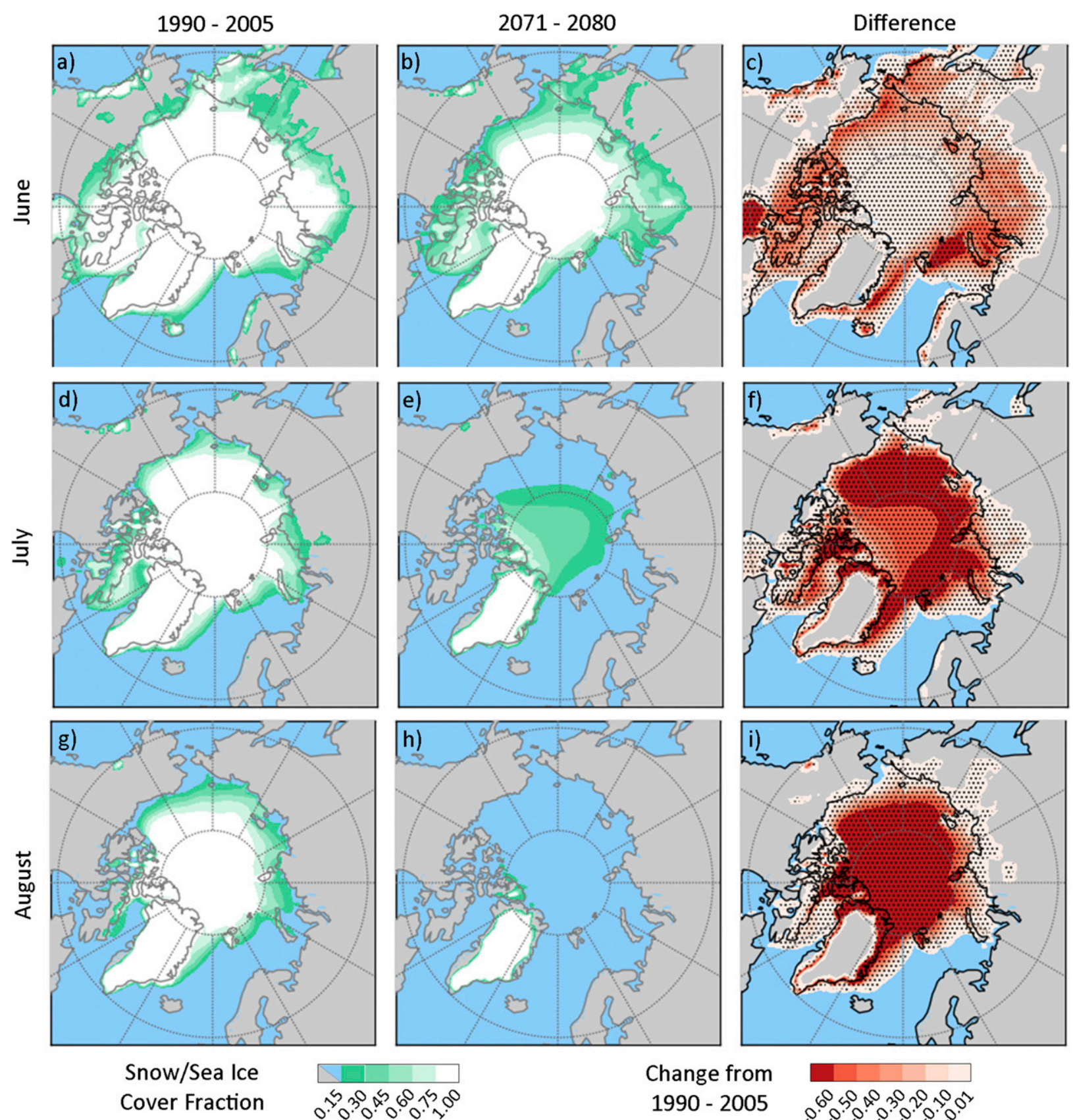

FIG. 13. As in Fig. 8, but for mean June-August snow cover and sea ice concentration based on the CESM-LE ensemble mean.

intensity north of the Laptev Sea and increased frequency and intensity north of Svalbard but little change overall.

A bias in CESM that may impact its results is that in comparison to atmospheric reanalyses, CESM overestimates both cyclogenesis and track density over Siberia, including within the AFZ, and underestimates them over the Arctic Ocean (Fig. S14). It is uncertain how this bias affects our results. That Orsolini and
Sorteberg (2009) came to a similar conclusion about track density changes using a different model and cyclone detection and tracking algorithm argues that the effect is minor. However, their model, like CESM, also underestimates track density within the CAO+BCEL.

As with cyclones migrating from the North Atlantic, cyclones migrating from Eurasia in June are generally weaker in $2071-80$, with a difference of $-0.08 \mathrm{hPa}$ $(100 \mathrm{~km})^{-2}(-5.0 \% ; p<0.01)$ before entering the 
$\mathrm{CAO}+\mathrm{BCEL}$ region. Despite some strengthening of the $\mathrm{AFZ}$ on the eastern end of Eurasia, the intensification rate of cyclones passing through the AFZ exhibits no significant change. However, the AFZ does change in one regard: in 2071-80 more cyclones are generated within the AFZ but fewer preexisting cyclones migrate through it (Fig. 9c). Because of this poleward shift in cyclogenesis, in the warming scenario cyclones from Eurasia are $12 \mathrm{~h}$ younger on average at the time they move into the CAO+BCEL $(p<0.01)$. In both 1990 2005 and $2071-80$, the maximum intensity for such cyclones occurs on average about $12 \mathrm{~h}$ after leaving the AFZ. This means that cyclones in 2071-80 have less time to develop and deepen. Once they reach the Arctic Ocean, these storms usually begin to stagnate and dissipate regardless of age or intensity. Hence, the intensification period for these cyclones is shortened.

An exception to June weakening is the group of cyclones migrating into the $\mathrm{CAO}+\mathrm{BCEL}$ region from northwest North America. These cyclones are stronger on average by $0.09 \mathrm{hPa}(100 \mathrm{~km})^{-2}(6.4 \% ; p<0.01)$ in 2071-80 before entry into the CAO+BCEL. The Alaskan and Yukon coastlines experience the greatest strengthening of the June AFZ (Fig. 4), which may be partly responsible. Indeed, the intensification rate for these cyclones while in the AFZ increases by $+0.08 \mathrm{hPa}(100 \mathrm{~km})^{-2}$ day $^{-1}$ $(p=0.04)$ without a significant change to cyclone age. However, as seen in Fig. 10c, this has only a small impact on the CAO+BCEL.

\section{d. Cyclone response in July and August}

Near the surface, the AFZ strengthens in only a few areas in July, and it weakens slightly in August (Fig. 4). Aloft, there is little change in either meridional temperature gradients or zonal wind velocity along the Arctic coastline of Eurasia despite widespread changes both north and south of the AFZ (Figs. 6 and 7). Cyclone frequency (Fig. 8) and intensity (Fig. 10) in the CAO also show relatively little change in July and August. While there is a shift in the seasonality of the AFZ, its role as a cyclone intensifier remains robust (Figs. 11 and 12). Hence, in many ways, the AFZ is a fixture of consistency in an otherwise changing Arctic in July and August.

However, looking along the Arctic coastline of northwest North America, meridional temperature gradients and zonal wind velocity both increase substantially in July and August (Figs. 6 and 7). Unlike the changes simulated for June, the strengthening of meridional temperature gradients in August at $154^{\circ} \mathrm{W}$ is not clearly tied to the surface. Indeed, directly above the coastline, temperature gradients actually weaken in August from 850 to $800 \mathrm{hPa}$. This behavior may not be limited to CESM. Over $80 \%$ of the models considered by Nishii et al. (2015) depicted strengthening of summer westerlies at $850 \mathrm{hPa}$ over the northwest North American coastline, with a multimodel ensemble mean change of $+0.4 \mathrm{~m} \mathrm{~s}^{-1}$. No obvious changes were depicted over the Eurasian coastline despite strengthening of nearsurface temperature gradients. Therefore, the surface response of snow and sea ice to the warming scenario cannot explain the changes to temperature gradients and zonal winds above the northwest North American coastline in July and August.

Along with these changes in Figs. 6 and 7, both track density and cyclone intensity increase in parts of the Beaufort and Chukchi Seas during July and August (Figs. 8 and 10). However, unlike in June, cyclones passing through the North American part of the AFZ do not experience greater intensification in the warming scenario than in 1990-2005. There is also no increase in cyclogenesis along the coastline of the BCEL Seas. In other words, the enhanced cyclone activity in the Beaufort and Chukchi Seas in July and August occurs despite relatively little change to the AFZ.

What, then, is the cause? The major reduction in sea ice cover may lead to a greater surface latent heat flux, and therefore cyclone intensification (Simmonds and Keay 2009). However, cyclone intensification does not change over the Beaufort and Chukchi Seas under RCP8.5 in CESM, just cyclone intensity. This is consistent with Long and Perrie (2012), who found no change to summer cyclone intensification when sea ice was removed in a model experiment, as well as Koyama et al. (2017), who found no significant difference in cyclone intensity between low sea ice years and high sea ice years using atmospheric reanalyses despite differences in the latent heat flux.

Rather than local causes, the enhanced cyclone activity in these areas is most likely due to changes in the northern Eurasian and Pacific storm tracks. Figure 14 shows track density maps and spaghetti plots for cyclones generated in northeast Asia (Figs. 14a-f) and the North Pacific Ocean (Figs. 14g-1) for July-August 1990-2005 and 2071-80. July-August cyclogenesis in northeast Asia declines by $11 \%(p<0.01)$ under the warming scenario. Despite this decline, more storms migrate into the Chukchi and Beaufort Seas (Fig. 14c). Under RCP8.5, the northern Eurasian storm track becomes more zonal in July and August, and storms are more likely to hug the coastline. A similar pattern is apparent for storms forming over the Taymyr Peninsula (not shown).

There is also a shift in the North Pacific storm track. The track density in the Gulf of Alaska (GA) drops substantially between 1990-2005 and 2071-80 in all summer months (Fig. 8), but this is not simply because 
1990-2005
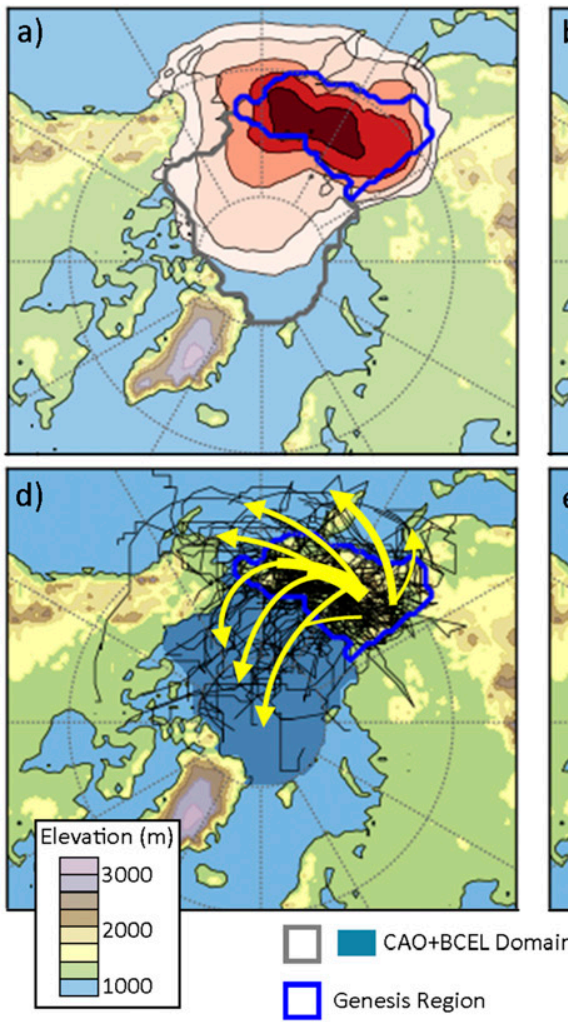

$2071-2080$
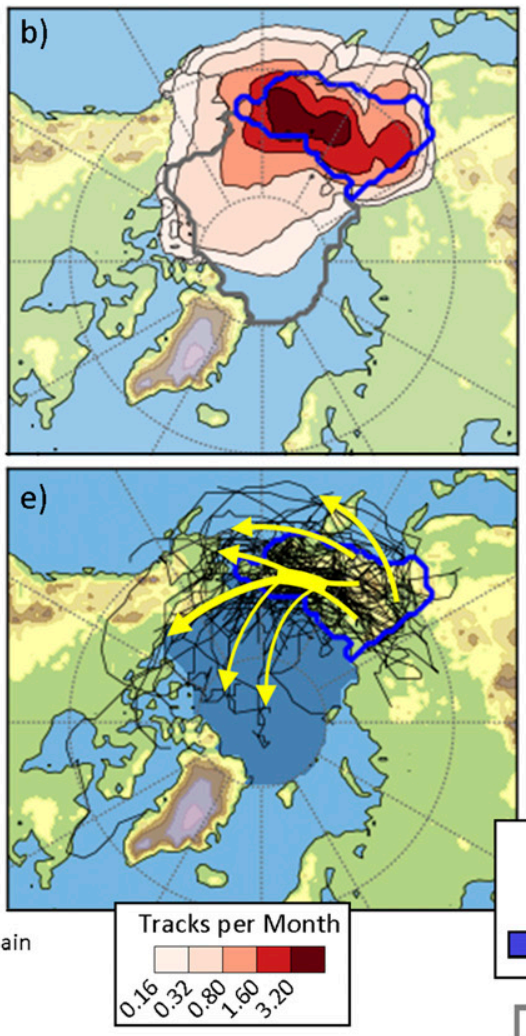

Difference
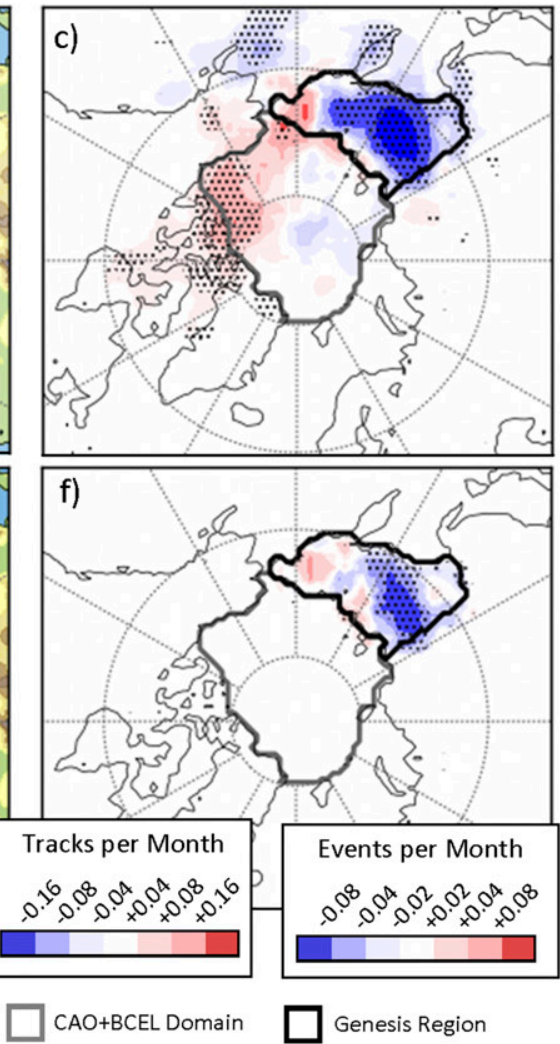
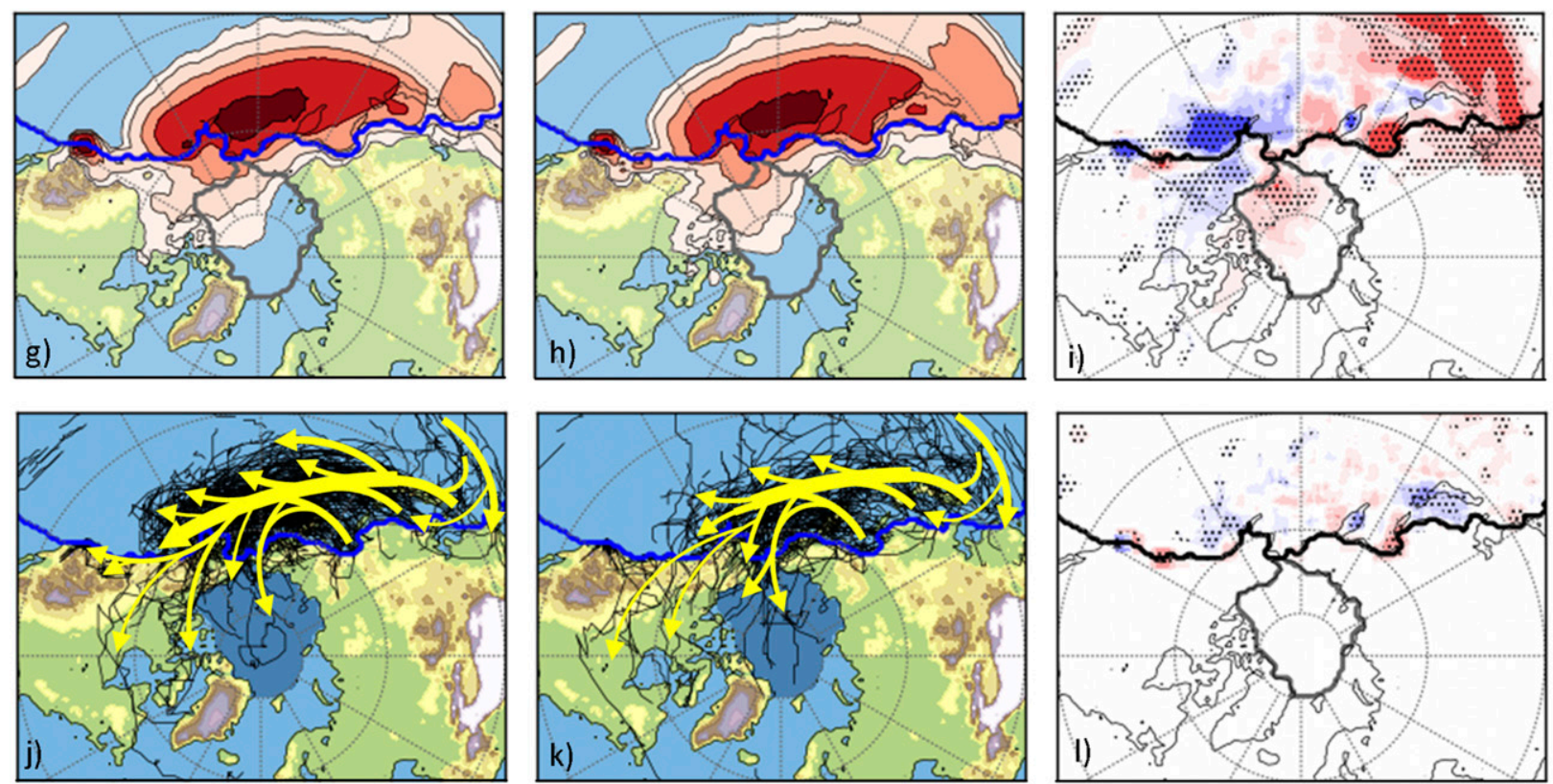

FIG. 14. (a),(b),(g),(h) Contour plots and (d),(e),(j),(k) spaghetti plots of cyclone tracks originating in (top) eastern Siberia and (bottom) the North Pacific Ocean (outlined in black or blue) during July-August of (left) 1990-2005 and (center) 2071-80. Also shown are the differences in (c),(i) track density and (f),(1) cyclogenesis frequency for cyclones originating in eastern Siberia. Stippling indicates a significant change based on the $95 \%$ confidence interval of the Student's $t$ test in which each member is considered an independent observation (30 observations per period). 
of a weakening storm track. As shown in Fig. 14i, more storms track through the Bering Strait (BS) in 2071-80 in July and August. Therefore, the increase in cyclone activity in the Beaufort and Chukchi Seas is due to shifting storm tracks, not additional cyclogenesis. Orsolini and Sorteberg (2009) also identify a poleward shift in the North Pacific storm track in the A2 scenario, but not as far north as depicted in CESM-LE.

In addition to greater cyclone activity, more frequent excursions of the polar front north of the Brooks Range (BR) might also explain the strengthening of midtroposphere meridional temperature gradients and zonal winds along the Alaskan coastline in July (Figs. 6a,e) and August (Figs. 7a,e). A subpolar influence is consistent with the lack of simulated surface changes in this area. This shows that the AFZ is just one influence of several on summer Arctic cyclone activity. Even though the AFZ is relatively stable under RCP8.5 in July and August, Arctic cyclone activity still changes.

\section{e. $C A P$}

Increased CAP occurs throughout the CAO+BCEL region. This is despite the lack of overall increases for either cyclone frequency or intensity. The increases, then, must be thermodynamically driven. Saturation vapor pressure increases with temperature, and enhanced latent heat exchange is a well-established response to global warming (O'Gorman et al. 2012; Pithan and Mauritsen 2014). The percent increase in CAP is smallest in June, which has weaker cyclones in 2071-80. The dynamic change, then, may partly offset the thermodynamic drivers. Additionally, July and August see a larger reduction in sea ice extent (Fig. 13), which may enhance moisture fluxes to the atmosphere (Screen and Simmonds 2010; Long and Perrie 2012; Vihma 2014; Koyama et al. 2017). Greater moisture input can also be expected from lower latitudes (O'Gorman et al. 2012), so the extra water vapor necessary for increased CAP may be both internally and externally sourced.

\section{Conclusions}

This paper has addressed potential future changes in summer Arctic cyclone activity, with a focus on the impacts of the AFZ. In July and August, the AFZ experiences little change above the near-surface level under RCP8.5, but June shows some strengthening along the Arctic coasts of eastern Siberia, Chukotka, and northwest North America. June strengthening occurs because snow cover melts earlier under RCP8.5, leading to amplified warming of air over the continents. Sea ice retreat also occurs earlier under RCP8.5, but the sea ice-albedo feedback to warming is delayed until later in the year.
Strengthening of the AFZ in June is accompanied by increases in cyclogenesis and cyclone intensification along some parts of the AFZ, but overall the CAO+BCEL region experiences no change to cyclone frequency and a decrease in cyclone intensity. Storms migrating into the $\mathrm{CAO}+\mathrm{BCEL}$ in June are weaker on average under RCP8.5, including those coming from Eurasia and the North Atlantic storm track. In July and August, enhanced cyclone activity in the Beaufort Sea appears most strongly related to shifts in the northern Eurasian and North Pacific storm tracks, not to changes in the AFZ.

These findings (as well as the large increase in CAP) provide evidence that the response of summer Arctic cyclone activity is strongly dependent on changes at lower latitudes. As Nishii et al. (2015) concluded, these external influences can override the influence of the AFZ. However, the AFZ maintains its year-to-year influence on cyclone intensity under RCP8.5. Therefore, regardless of the other changes in this warming scenario, the AFZ remains an important influence on summer Arctic cyclone development.

Acknowledgments. We thank the editor and two anonymous reviewers for their comments. This material is based upon work supported by the National Science Foundation (NSF) Graduate Research Fellowship Program under Grant DGE-1144083 and by NSF Grant PLR-1417016. Any opinion, findings, and conclusions or recommendations expressed in this material are those of the authors and do not necessarily reflect the views of the National Science Foundation.

\section{REFERENCES}

Akperov, M., I. Mokhov, A. Rinke, K. Dethloff, and H. Matthes, 2015: Cyclones and their possible changes in the Arctic by the end of the twenty first century from regional climate model simulations. Theor. Appl. Climatol., 122, 85-96, doi:10.1007/ s00704-014-1272-2.

Bengtsson, L., K. I. Hodges, and N. Keenlyside, 2009: Will extratropical storms intensify in a warmer climate? J. Climate, 22, 2276-2301, doi:10.1175/2008JCLI2678.1.

,-- S. Koumoutsaris, M. Zahn, and N. Keenlyside, 2011: The changing atmospheric water cycle in polar regions in a warmer climate. Tellus, 63A, 907-920, doi:10.1111/ j.1600-0870.2011.00534.x.

Brodzik, M. J., B. Billingsley, T. Haran, B. Raup, and M. H. Savoie, 2012: EASE-Grid 2.0: Incremental but significant improvements for Earth-gridded data sets. ISPRS Int. J. Geo-Inf., 1, 32-45, doi:10.3390/ijgi1010032.

Brown, R. D., and D. A. Robinson, 2011: Northern Hemisphere spring snow cover variability and change over 1922-2010 including an assessment of uncertainty. Cryosphere, 5, 219-229, doi:10.5194/tc-5-219-2011.

Catto, J. L., C. Jakob, G. Berry, and N. Nicholls, 2012: Relating global precipitation to atmospheric fronts. Geophys. Res. Lett., 39, L10805, doi:10.1029/2012gl051736. 
Chang, E. K. M., Y. Guo, and X. Xia, 2012: CMIP5 multimodel ensemble projection of storm track change under global warming. J. Geophys. Res., 117, D23118, doi:10.1029/2012JD018578.

Collins, M., and Coauthors, 2013: Long-term climate change: Projections, commitments and irreversibility. Climate Change 2013: The Physical Science Basis, T. F. Stocker et al., Eds., Cambridge University Press, 1029-1136.

Crawford, A. D., and M. C. Serreze, 2015: A new look at the summer Arctic Frontal Zone. J. Climate, 28, 737-754, doi:10.1175/JCLI-D-14-00447.1.

- , and -2016 : Does the summer Arctic Frontal Zone influence Arctic Ocean cyclone activity? J. Climate, 29, 49774993, doi:10.1175/JCLI-D-15-0755.1.

Finnis, J., M. M. Holland, M. C. Serreze, and J. J. Cassano, 2007: Response of Northern Hemisphere extratropical cyclone activity and associated precipitation to climate change, as represented by the Community Climate System Model. J. Geophys. Res., 112, G04S42, doi:10.1029/2006JG000286.

Hanley, J., and R. Caballero, 2012: Objective identification and tracking of multicentre cyclones in the ERA-Interim reanalysis dataset. Quart. J. Roy. Meteor. Soc., 138, 612-625, doi:10.1002/qj.948.

Hurrell, J. W., and Coauthors, 2013: The Community Earth System Model: A framework for collaborative research. Bull. Amer. Meteor. Soc., 94, 1339-1360, doi:10.1175/BAMS-D-12-00121.1.

Jaiser, R., K. Dethloff, D. Handorf, A. Rinke, and J. Cohen, 2012: Impact of sea ice cover changes on the Northern Hemisphere atmospheric winter circulation. Tellus, 64A, 11595, doi:10.3402/ tellusa.v64i0.11595.

Kay, J. E., and Coauthors, 2015: The Community Earth System Model (CESM) large ensemble project: A community resource for studying climate change in the presence of internal climate variability. Bull. Amer. Meteor. Soc., 96, 1333-1349, doi:10.1175/BAMS-D-13-00255.1.

Koyama, T., J. Stroeve, J. J. Cassano, and A. Crawford, 2017: Sea ice loss and Arctic cyclone activity from 1979 to 2014. J. Climate, 30, 4735-4754, doi:10.1175/JCLI-D-16-0542.1.

Lang, C., and D. W. Waugh, 2011: Impact of climate change on the frequency of Northern Hemisphere summer cyclones. J. Geophys. Res., 116, D04103, doi:10.1029/2010JD014300.

Lehmann, J., D. Coumou, K. Frieler, A. Eliseev, and A. Levermann, 2014: Future changes in extratropical storm tracks and baroclinicity under climate change. Environ. Res. Lett., 9, 084002, doi:10.1088/1748-9326/9/8/084002.

Long, Z., and W. Perrie, 2012: Air-sea interactions during an Arctic storm. J. Geophys. Res., 117, D15103, doi:10.1029/ $2011 \mathrm{jd} 016985$.

Lorenz, E. N., 1963: Deterministic nonperiodic flow. J. Atmos. Sci., 20, 130-141, doi:10.1175/1520-0469(1963)020<0130:DNF>2.0.CO;2.

Nishii, K., H. Nakamura, and Y. J. Orsolini, 2015: Arctic summer storm track in CMIP3/5 climate models. Climate Dyn., 44, 1311-1327, doi:10.1007/s00382-014-2229-y.

Ogi, M., K. Yamazaki, and Y. Tachibana, 2004: The summertime annular mode in the Northern Hemisphere and its linkage to the winter mode. J. Geophys. Res., 109, D20114, doi:10.1029/ 2004JD004514.

O'Gorman, P. A., R. P. Allan, M. P. Byrne, and M. Previdi, 2012: Energetic constraints on precipitation under climate change. Surv. Geophys., 33, 585-608, doi:10.1007/s10712-011-9159-6.

Orsolini, Y. J., and A. Sorteberg, 2009: Projected changes in Eurasian and Arctic summer cyclones under global warming in the Bergen Climate Model. Atmos. Oceanic Sci. Lett., 2, 62-67, doi:10.1080/16742834.2009.11446776.
Papritz, L., S. Pfahl, I. Rudeva, I. Simmonds, H. Sodemann, and H. Wernli, 2014: The role of extratropical cyclones and fronts for Southern Ocean freshwater fluxes. J. Climate, 27, 62056224, doi:10.1175/JCLI-D-13-00409.1.

Pinto, J. G., U. Ulbrich, G. C. Leckebusch, T. Spangehl, M. Reyers, and S. Zacharias, 2007: Changes in storm track and cyclone activity in three SRES ensemble experiments with the ECHAM5/MPI-OM1 GCM. Climate Dyn., 29, 195-210, doi:10.1007/s00382-007-0230-4.

Pithan, F., and T. Mauritsen, 2014: Arctic amplification dominated by temperature feedbacks in contemporary climate models. Nat. Geosci., 7, 181-184, doi:10.1038/ngeo2071.

Porter, D. F., J. J. Cassano, and M. C. Serreze, 2012: Local and large-scale atmospheric responses to reduced Arctic sea ice and ocean warming in the WRF model. J. Geophys. Res., 117, D11115, doi:10.1029/2011JD016969.

Reed, R. J., and B. A. Kunkel, 1960: The Arctic circulation in summer. J. Meteor., 17, 489-506, doi:10.1175/1520-0469(1960)017<0489: TACIS $>2.0 . \mathrm{CO} ; 2$.

Rinke, A., K. Dethloff, W. Dorn, D. Handorf, and J. C. Moore, 2013: Simulated Arctic atmospheric feedbacks associated with late summer sea ice anomalies. J. Geophys. Res. Atmos., 118, 7698-7714, doi:10.1002/jgrd.50584.

Schuenemann, K. C., and J. J. Cassano, 2010: Changes in synoptic weather patterns and Greenland precipitation in the 20th and 21st centuries: 2 . Analysis of 21st century atmospheric changes using self-organizing maps. J. Geophys. Res., 115, D05108, doi:10.1029/2009JD011706.

Screen, J. A., and I. Simmonds, 2010: The central role of diminishing sea ice in recent Arctic temperature amplification. Nature, 464, 1334-1337, doi:10.1038/nature09051.

Serreze, M. C., 1995: Climatological aspects of cyclone development and decay in the Arctic. Atmos.-Ocean, 33, 1-23, doi:10.1080/07055900.1995.9649522.

— the central Arctic Ocean. J. Climate, 21, 1048-1065, doi:10.1175/2007JCLI1810.1.

— , and J. C. Stroeve, 2008: Standing on the brink. Nat. Rep. Climate Change, 2, 142-143, doi:10.1038/climate.2008.108.

— plification: A research synthesis. Global Planet. Change, 77, 85-96, doi:10.1016/j.gloplacha.2011.03.004.

_ J. E. Box, R. G. Barry, and J. E. Walsh, 1993: Characteristics of Arctic synoptic activity, 1952-1989. Meteor. Atmos. Phys., 51, 147-164, doi:10.1007/BF01030491.

—, A. H. Lynch, and M. P. Clark, 2001: The Arctic frontal zone as seen in the NCEP-NCAR reanalysis. J. Climate, 14, 1550-1567, doi:10.1175/1520-0442(2001)014<1550: TAFZAS $>2.0 . \mathrm{CO} ; 2$.

_ A. P. Barrett, J. C. Stroeve, D. N. Kindig, and M. M. Holland, 2009: The emergence of surface-based Arctic amplification. Cryosphere, 3, 11-19, doi:10.5194/tc-3-11-2009.

,-- , and J. J. Cassano, 2011: Circulation and surface controls on the lower tropospheric air temperature field of the Arctic. J. Geophys. Res., 116, D07104, doi:10.1029/2010JD015127.

Simmonds, I., and K. Keay, 2000: Mean Southern Hemisphere extratropical cyclone behavior in the 40-year NCEP-NCAR reanalysis. J. Climate, 13, 873-885, doi:10.1175/1520-0442 (2000)013<0873:MSHECB > 2.0.CO;2.

_ and - 2009: Extraordinary September Arctic sea ice reductions and their relationships with storm behavior over 1979-2008. Geophys. Res. Lett., 36, L19715, doi:10.1029/ 2009GL039810. 
- and I. Rudeva, 2014: A comparison of tracking methods for extreme cyclones in the Arctic basin. Tellus, 66A, 25252, doi:10.3402/tellusa.v66.25252.

_- C. Burke, and K. Keay, 2008: Arctic climate change as manifest in cyclone behavior. J. Climate, 21, 5777-5796, doi:10.1175/2008JCLI2366.1.

Sorteberg, A., and J. E. Walsh, 2008: Seasonal cyclone variability at $70^{\circ} \mathrm{N}$ and its impact on moisture transport into the Arctic Tellus, 60A, 570-586, doi:10.1111/j.1600-0870.2008.00314.x.

Stroeve, J. C., M. C. Serreze, A. Barrett, and D. N. Kindig, 2011: Attribution of recent changes in autumn cyclone associated precipitation in the Arctic. Tellus, 63A, 653-663, doi:10.1111/ j.1600-0870.2011.00515.x.

_ , V. Kattsov, A. Barrett, M. C. Serreze, T. Pavlova, M. M. Holland, and W. N. Meier, 2012: Trends in Arctic sea ice extent from CMIP5, CMIP3 and observations. Geophys. Res. Lett., 39, L16502, doi:10.1029/2012GL052676.

Tilinina, N., S. K. Gulev, I. Rudeva, and P. Koltermann, 2013: Comparing cyclone life cycle characteristics and their interannual variability in different reanalyses. J. Climate, 26, 6419-6438, doi:10.1175/JCLI-D-12-00777.1.

Ulbrich, U., J. G. Pinto, H. Kupfer, G. C. Leckebusch, T. Spangehl, and M. Reyers, 2008: Changing Northern Hemisphere storm tracks in an ensemble of IPCC climate change simulations. J. Climate, 21, 1669-1679, doi:10.1175/ 2007JCLI1992.1.

, G. C. Leckebusch, and J. G. Pinto, 2009: Extra-tropical cyclones in the present and future climate: A review. Theor. Appl. Climatol., 96, 117-131, doi:10.1007/s00704-008-0083-8.

- , and Coauthors, 2013: Are greenhouse gas signals of Northern Hemisphere winter extra-tropical cyclone activity dependent on the identification and tracking algorithm? Meteor. Z., 22, 61-68, doi:10.1127/0941-2948/2013/0420.

Vihma, T., 2014: Effects of Arctic sea ice decline on weather and climate: A review. Surv. Geophys., 35, 1175-1214, doi:10.1007/ s10712-014-9284-0.

Wernli, H., and C. Schwierz, 2006: Surface cyclones in the ERA-40 dataset (1958-2001). Part I: Novel identification method and global climatology. J. Atmos. Sci., 63, 2486-2507, doi:10.1175/ JAS3766.1.

Whittaker, L. M., and L. H. Horn, 1984: Northern Hemisphere extratropical cyclone activity for four mid-season months. J. Climatol., 4, 297-310, doi:10.1002/joc.3370040307.

Zappa, G., L. C. Shaffrey, K. I. Hodges, P. G. Sansom, and D. B. Stephenson, 2013: A multimodel assessment of future projections of North Atlantic and European extratropical cyclones in the CMIP5 climate models. J. Climate, 26, 5846-5862, doi:10.1175/JCLI-D-12-00573.1. 